\title{
SZEMLE
}

\section{Modellezés és modellhasználat a talajtani kutatásban}

A talaj, mint a legtöbb természeti képződmény túlságosan összetett ahhoz, hogy egyszerủen vizsgálható, leírható, és müködésében, fejlődésében, változásában elemezhetö legyen. Az elemző emberi elme az összetett jelenségeket, szerkezeteket lényeges jellemzöik megtartásával, egyszerübb helyettesítőikkel, modelljeikkel cseréli fel annak érdekében, hogy azok müködését meghatározott, de a valóságosnál egyszerübb, átláthatóbb feltételek között tanulmányozhassa. A modell tehát a komplex valóság elméletileg és szemléletileg meghatározott leképezése (RICHTER, 1987). A tudomány művelői mindezt az újkor egyik legnagyobb szellemi vívmánya, a természetre, a világra modellel történő rákérdezés lehetőségét felismerve teszik. JUHÁsz-NAGY (1993) szerint: „Ha ez a rákérdezés legalább részben formális (matematikai), akkor bizonyosan valamilyen modellről beszélhetünk. Már a rákérdezés módja és formája is jelzi, hogy a modellezés, modellalkalmazás során az egyszerüsítés szükséglet. Minden modell egy szakmai szükséglet és egy matematikai lehetőség találkozási pontján jöhet létre.” A továbbiakban az ún. számítógépes, vagy matematikai modellezés témakörét tekintjük át.

A modell a valóságot képezi le, jeleníti meg, helyettesíti, vagyis reprezentálja, még ha egyszerüsített formában is (ADDISCOTT, 1993). ADDISCOTT a talajra, mint összetett rendszerre, valamint egy ember által készített eszközre, egy csónakra vonatkozó modellek közötti különbség példáján fejti ki, hogy míg a „csónakmodell” minden lényeges jellemzöje egyértelmü és ismert, addig a talajmodell esetében annak eldöntése, hogy melyek a fontos és a jellemző tulajdonságok, hipotézis kérdése, illetve jelentős bizonytalanság társul bármely részletre vonatkozó érték megadásához. Azt a következtetést vonja le, hogy a talajmodellek hipotetikus természetüek, vagyis a modell építésekor alkalmazott feltételezések döntő jelentőségúek. A hipotézisek gyakran szavakban, a jelenséget leíró egyenletek megválasztásában, a nem mérhető paramétereknek adott értékben, a modellben párhuzamosan futó folyamatok sorrendjének megválasztásában stb. foglalhatók össze. A talaj természete, és a talajban végbemenő folyamatok száma miatt egy talajmodellben rendszerint több, egymással kölcsönhatásban álló egyenlet szerepeltetése szükséges. A több egyenletből felépülő modelleket célszerü emiatt kiterjesztett hipotézisü modelleknek nevezni. A kiterjesztett hipotézisü modelleket szintén mért adatokon célszerü tesztelni oly módon, hogy a modell feltételrendszerét (hipotéziseit), ha szükséges, át is lehessen alakítani. A modelltesztelésnek ezt a módját érvényesítésnek, validálásnak nevezzük. Az érvényesített modell eredményéről, a modell által adott elörejelzésről tudni kell, hogy az nem vonatkoztatható a modell érvényességi tartományán kívül.

Összetett rendszerek müködésének leírását tehát a matematika, a fizika, vagy a kémia formanyelvét alkalmazó egyenletrendszerek szolgálják, és adott kezdeti értékről 
indulóan megoldásuk adja a rendszer válaszát. Azonban a bonyolult differenciálegyenletek numerikus megoldásának a lehetősége elég egyértelmüen a számítás-, illetve a számítógép technika fejlődéséhez kötődött. A számítástechnika utóbbi tizenöt évben végbement fejlődésének köszönhetően ma már a személyi számítógépek lehetővé teszik a számítógépes modellek használatát és/vagy továbbfejlesztését.

A modellépítés és alkalmazás nem csupán azt jelenti, hogy a kutatók és a gyakorlati szakemberek egy kutatást segítő, illetve egy rákérdezést lehetővé tevő eszközzel gazdagodtak, hanem a modellépítő és alkalmazó egyúttal rákényszerül arra, hogy a vonatkozó tudományterület általános ismereteit és feltételezéseit összegyüjtse, rendszerezze, a modellezésben azokat alkalmazza, illetve érvényességüket kipróbálja. A modellépítők egyik csoportja minden feladatra egyedi modellt fejleszt ki, míg a másik csoport tagjai a hasonló feladatokra egyetlen közös modellt építenek. A modellalkalmazás, vagy modell-módszer számos elöremutató ismérve közül néhány:

- a modellezett rendszer aktuális ismeretanyagának a feldolgozása;

- az összetett rendszer egyes építőelemeinek egységes, müködő egésszé történő összekapcsolása, vagyis az aktuális ismeretek szintetizálása;

- az aktuális ismeretek és elméletek alapján annak ellenőrzése, hogy a mennyiségek, mértékegységek szerint, vagyis kvantitatív módon mennyire tekinthető igaznak a modellezett rendszer müködéséről alkotott feltevés (hipotézis), vagy hipotézis rendszer;

- a tudományos ismeretek elfogadottsága alapján kutatási preferenciák kijelölése;

- a modell segítségével térben és időben elörejelzések készítése.

Belátható, hogy a modellezés általánosan alkalmazható minden tudományterületen. Talajtani alkalmazása is rendkívül sokszínű és sokféle. Áttekintésünk a talajfejlődés, a talajfejlődést előidéző, mozgató és befolyásoló talajfolyamatok modelljeinek a számbavételére szorítkozik.

A modell-módszer fejlődésének a szükségességét, vagyis azt, hogy a talajkörnyezeti és a talajfejlődési folyamatok modellezhetők legyenek, egyre sürgetőbbé vált a globális klímaváltozás várható hatásainak elörejelzése kapcsán. A talajok ugyanis kulcsszerepet játszanak az ökoszisztémák felépítésében és müködésében egyaránt. Részben kiegyenlítik, részben elszenvedik a globális változások hatásait. Annak érdekében, hogy a talaj ökológiai szerepe megérthető legyen, egyrészt magában a talajban lejátszódó folyamatokat, másrészt a talaj- és az ökológiai rendszer más elemei közötti kapcsolatokat szükséges tisztázni. A talajnak, mint összetett, sok alkotórészből álló rendszer tanulmányozásának ez a rendszerszemléletű módja a talajtannak a kezdetektől fogva jellemzője (DOKUCSAJEV, 1883; STEBUTT, 1930), és ma is alapját képezi a talajtani modellezésnek és modelleknek. Megállapítható, hogy az 1970-es évek végétől a laboratóriumi és a szabadföldi kísérletek mellett a számítógépes modellezés, a szimulációs módszer az ismeretszerzés, ellenőrzés és előrejelzés eszközévé vált. A számítógépes modellhasználat nemcsak kutatási, hanem oktatási, szaktanácsadási és ismeretközlő eszközzé és módszerré is vált. 


\section{A talajmodellezés története}

A nyugati világban „a talajképződés tényezői” általános és „kvalitatív” talajmodelljének megalkotása JENNY (1941) nevéhez füződik, és a legismertebb. A Jenny-féle talajmodellben a dokucsajevi talajképződési tényezők, a topográfia (felszínalaktan), anyakőzet (geológiai alap), az éghajlat (hőmérséklet és nedvesség), a biológiai aktivitás (a flóra és a fauna, az embert is beleértve), valamint mindezek időbeli hatásai a talajra (a talaj kora) szerepelnek. A felsorolt talajképződési tényezők a kezdeti állapothoz képest együttesen határozzák meg a talaj tulajdonságainak alakulását (JENNY, 1941, 1980). Ez a szemlélet jellemzi a talajtan szinte minden területét, a talajfelvételezéstől kezdve egészen a talajinformációs rendszerekben létrehozott digitális információ-rétegekig. A felsorolt talajképződési tényezők, mint állapothatározók (state factors) határozzák meg a talajfejlődést. A talajképződés mennyiségi leírása is ezen az alapon történik.

A hazai talajtanban a talajképződés és talajfejlődés folyamatainak együttes figyelembevételével készült rendszer alapját a talajon felismerhető bélyegek kialakulásához vezető jelenségek folyamattársulása jelenti (STEFANOVITS, 1963, 1975; STEFANOVITS et al., 1999). Ebben a talajrendszerben kifejezésre jut a folyamatok szerepének erőssége is, amelyet a folyamatok négy szintre osztása rangsorol: uralkodó, jellemző, kísérő és módosító folyamatokat különböztetve meg. A talajtípus meghatározására az uralkodó, a jellemző és a kísérő folyamatok együttese szolgál. A módosító folyamatokat a talajváltozatok elkülönítésére használják.

Stefanovits hangsúlyozza, hogy a talajfolyamatok nem egymástól elkülönülten, függetlenül, hanem egymással kölcsönhatásban, meghatározott időrendi sorrendben és intenzitással vannak jelen és működnek. Alapvető jelentőségű az a felismerés, hogy a folyamatok fellépésének sem a sorrendje, sem az időpontja nem előre meghatározott. A talajfejlődés irányát a természeti viszonyok által meghatározott talajképződési tényezők időben történő megjelenése, hatástartama és erőssége eredményének tekinti. A talajfejlődés többirányú, poligenetikus jellegét a talajképződési folyamatok időbeni fellépéséből, hatástartamából és intenzitásbeli alakulásából vezeti le.

Stefanovits a talajképződést tehát az időben egymás után következő, vagy egy időben, többnyire különböző intenzitással végbemenő folyamatok eredményének tekinti. Nyilvánvaló, hogy a talajfejlődést a talajfejlődési modellben megfogalmazott koncepció alapján leíró matematikai modell részfolyamatainak mind felírása, mind összekapcsolása a modellkészítőket bonyolult feladat elé állítja.

A talajfejlődés modellezésének a 90-es évek eleji állapotáról HOOSBEEK és BRYANT (1992) összeállítása ad jó áttekintést. A mennyiségi modellek többsége egy-egy elkülönült fizikai, kémiai, vagy ásványtani folyamat leírására szorítkozik, és ezen túlmenően is egyszerű rendszerre írják le a folyamatot (pl. a kémiai anyagok kimosódását a talajszelvényből, a kémiai vegyületek geokémiai átalakulását, vagy a víz- és a hőáramlási folyamatok fizikáját). Ezek a modellek hatékonyak egy-egy talajfolyamat müködési mechanizmusának és/vagy bekövetkezési valószínüségének bemutatására, illetve a modellezett talajjellemző valamely állapotértékének az előrejelzésére. Ezek az egyszerü modellek azonban a modellezett folyamat talajfejlődés szempontú leírását nem teszik 
lehetővé. A talajfejlődés leírását az ún. „feladatvezérelt” (object oriented) modellezési, modellépítési technika és programozás segíti (BOOCH, 1991).

\section{A feladat által vezérelt modellezési technika}

A számítástechnikában, a modellépítésben és programnyelvekben végbement fejlödés már lehetőséget ad a folyamatvezérelt talajfejlődés modellezésére. A személyi számítógépeken elterjedt operációs rendszerek lehetővé teszik a számítógép processzor müködésének speciális programokhoz való illesztését. A fejlődés, amely a személyi számítógépes operációs rendszerekben és a felhasználói felületeken végbement a tudományos igényü modellezésben is nyomon követhető. Azok a fejlődési lépcsők, amelyek a 90-es évek elejére tehetők, pl. a Simula nyelv kifejlesztéséhez (WEGNER, 1990) és a Smalltalk felhasználói felülethez köthetően vezettek a feladatvezérelt modellezési technika kialakulásához (MEYER, 1988; BOOCH, 1991). A „feladatmodellezési technika” (RUMBAUGH et al., 1991) a feladatvezérelt programnyelven írt modellek feladatait, tárgyait oly módon rendezi össze, hogy összekapcsolásuk határozza meg az egyik modulból a másikba jutó információt és a végrehajtandó müveletet is. A hagyományos programokhoz képest - amelyek mindig ugyanazokat a müveleteket hajtják végre a különböző típusú adatokon - ezáltal egy szabályozott viselkedési tartomány kialakítása történik meg. Az azonos szerkezetű objektumok egy „osztályt” alkotnak. Az osztályhoz tartozás pedig megszabja az adatszerkezetet, a müveleteket és az alkalmazható módszereket. A feladatvezérelt programban a modulok között „üzenetek” és nem adatok mennek körbe, valamint az üzenetek szabják meg a végrehajtandó müveleteket. Egy feladatvezérelt adatbázisból a kérdéses adat kiválasztása anélkül történik meg, hogy külön meg kellene határozni az ahhoz szükséges rutint. Annak ellenére, hogy a feladatvezérelt modellezés elnevezései szerzőnként különbözőek, az elvi alapok egységesek (JACOBSON, 1993).

A feladatvezérelt programok nyelve a már korábban is említett Smalltalk, a CLOS, vagy a $\mathrm{C}++$. Az említett nyelvü programok illeszthetők a régebbi $\mathrm{C}$, Ada, vagy a Fortran77 programnyelven megírt programokhoz.

\section{A talajgenetikai modellezés lehetőségei}

A feladatvezérelt programozás lehetővé teszi a talajfejlődés szimulációját oly módon, hogy a talajszelvény kezdeti állapotának környezeti hatásokra bekövetkező változásai legyenek kijelezhetők. Az újonnan kialakuló talajtulajdonságok hatásai, a talajt magában foglaló ökológiai rendszer egyéb összetevőire vonatkozóan is kijelzésre kerülnek.

A talajfejlődés feladatvezérelt módon történő modellezése a következők tanulmányozását teszi lehetővé:

1. A szimuláció időlépték-változtatását, amire a különböző talajfolyamat sebességek kapcsán van elsősorban szükség. A talajfolyamatokat három időléptékre osztják fel: rövid idejü (napi, évszakos), középhosszú idejü (10-100 év), és a hosszú idejü (geológiai időlépték; ezer év). A rövid idejü tulajdonságok az aktuálisan ható talajfeltételek 
dinamikáját tükrözik, amelyek egyben a növényi életfolyamatok, a mezőgazdasági földhasználat és a növénytermesztés erőforrásai. A közép idejü tulajdonságok azok, amelyek a globális változásokkal vannak összefüggésben és határozzák meg, hogy a talaj hogyan hat a vegetáció egészségére, vagy szukcessziójára, valamint rajtuk keresztül mérhető le egy-egy meghatározott jelenség, vagy hatás erőssége is. A hosszú távú, geológiai idejü tulajdonságok a talajszelvény fejlödését és morfológiai tulajdonságait fejezik ki, amelyek egyben megszabják a talaj növénytermesztési potenciálját. Az 1. táblázatban néhány talajtulajdonság megváltozásának időléptékét mutatjuk be.

\section{1. táblázat}

Összeállítás a talajtulajdonságok változásának időléptékéről (RICHTER (1987) és ARNOLD és munkatársai (1990) után)

\begin{tabular}{|c|c|c|}
\hline \multicolumn{3}{|c|}{ Néhány talajjellemző megváltozásának időtartama } \\
\hline $\begin{array}{c}\text { Rövid idejü } \\
\text { (egy naptól egy évszakig) }\end{array}$ & $\begin{array}{c}\text { Közepes idejü } \\
\text { (1 évtől } 10 \text { évig) }\end{array}$ & $\begin{array}{c}\text { Hosszú idejü } \\
\text { (évszázadtól geológiai ideig) }\end{array}$ \\
\hline $\begin{array}{l}\text { hőmérséklet } \\
\text { nedvesség } \\
\text { gázösszetétel }\end{array}$ & $\begin{array}{l}\mathrm{pH} \\
\text { tápanyagállapot } \\
\text { szervesanyag-összetétel } \\
\text { mikrobiális életközösség } \\
\text { térfogattömeg } \\
\text { porozitás } \\
\text { beszivárgás } \\
\text { víztartóképesség } \\
\text { szerkezet } \\
\text { szeszkvioxid-tartalom }\end{array}$ & $\begin{array}{l}\text { ásványi összetétel } \\
\text { szemcseméret-eloszlás } \\
\text { szilárd fázis szemcséinek } \\
\quad \text { sürüsége }\end{array}$ \\
\hline
\end{tabular}

Természetesen, miközben a talajtulajdonságok változnak, az azokat kiváltó folyamatok is változáson mennek keresztül. Annak ellenére, hogy az 1. táblázatban az ásványi összetétel átalakulása hosszú idejü folyamatként szerepel, azt közepes időléptékủ folyamatként is figyelembe lehet venni. Míg például a rövid idejü folyamatok közül a csapadéktól és a kicserélődési mechanizmusoktól függően a talajoldat kémiája a legrövidebb időléptékben is változik. A szervesanyag-tartalom átalakulás, a térfogattömeg változás, vagy a tápanyag- és víztartó kapacitás változása a közepes időtartamú léptékre jellemző és szimulációjának időtartama is ebbe a tartományba helyezendő. Emiatt a talajmodellt oly módon szükséges felépíteni, hogy az mind a rövid, mind a hosszú időléptékü folyamatokat magába foglalja, és használatával érthetővé váljanak mind a rövidebb távon, mind a hosszabb távon jelentkezö következmények.

2. A talajfolyamatok és folyamategyüttesek, kölcsönhatások átfogó leirása. Az 1. ábra egy átfogó talajmodell koncepciójaként a föbb talajfolyamatok öt csoportja szerepel: ezek az abiotikus kémiai folyamatok (I), az élő szervezetek aktivitása (II), energia egyensúly és a vizes fázis átalakulási folyamatai (III), a vízáramlások (IV), a talajalkotó részek átrendeződése és újra eloszlása $(\mathrm{V})$. Az I-V. talajfolyamat csoport külön-külön is szerepelhet, mint szimulációs modelltípus (pl. talajfizikai, talajkémiai, vagy talajásványtani modellek). Bár az ábrán nem szerepel, az egyes talajfolyamat-osz- 

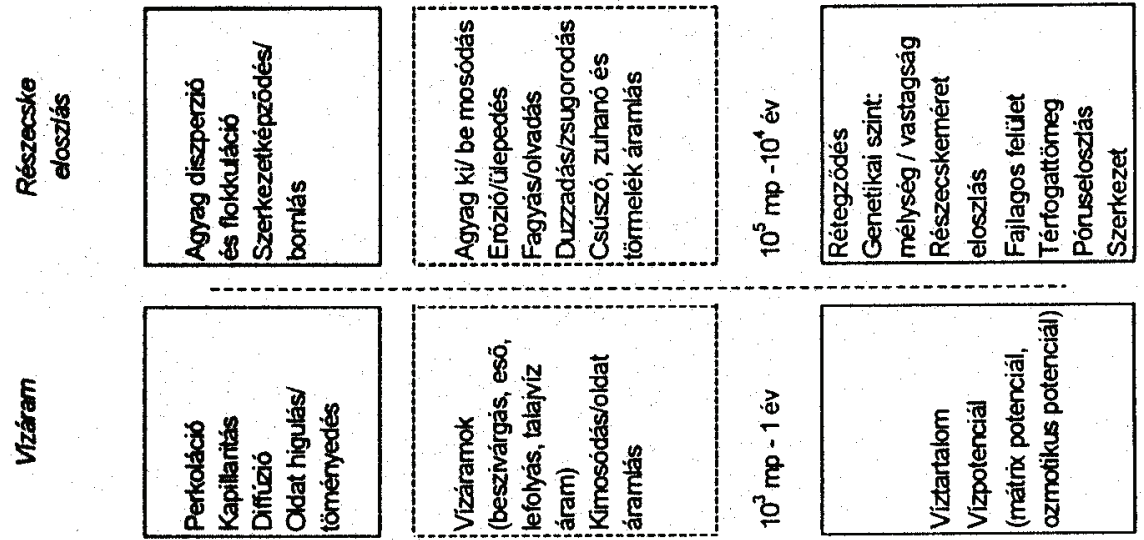

它
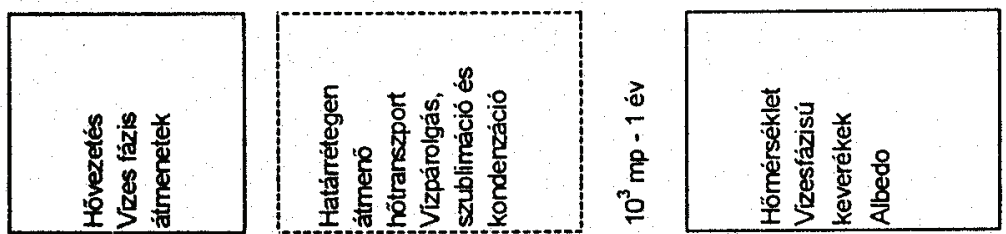

ขำ
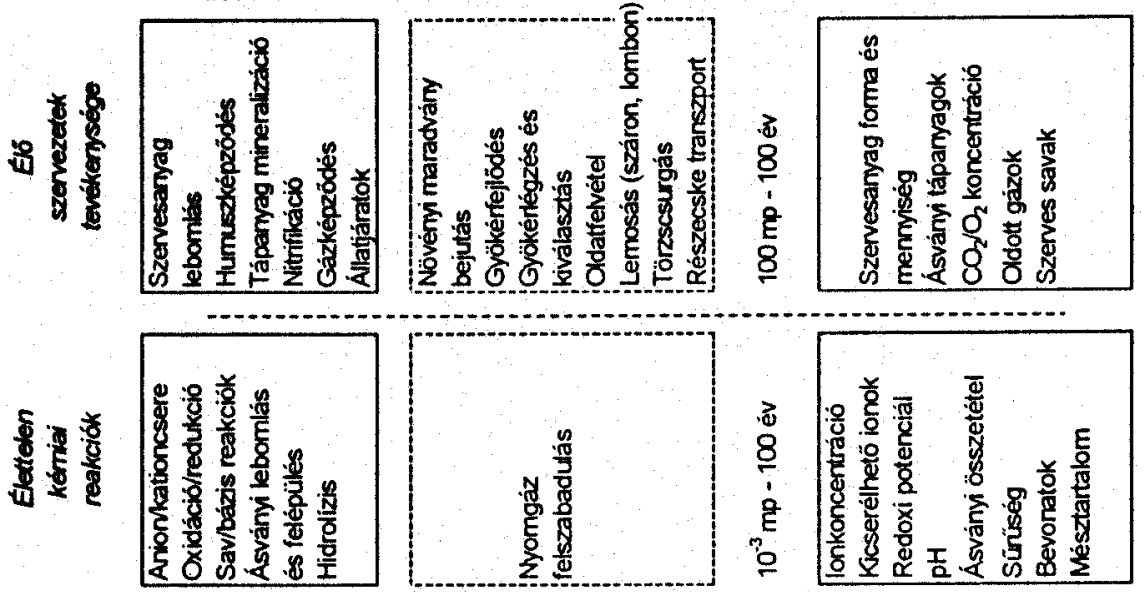

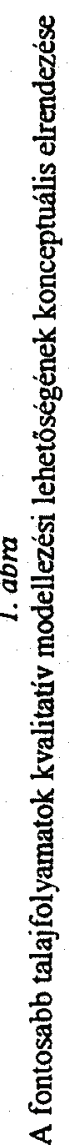
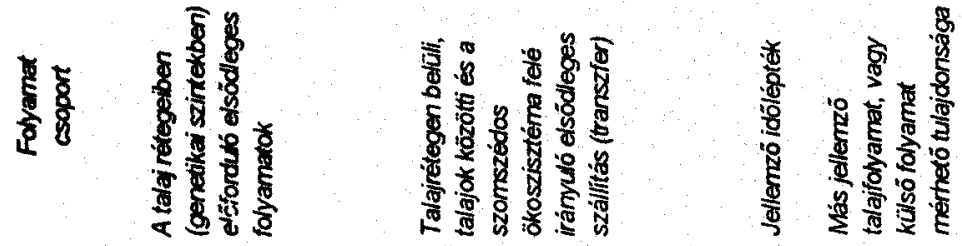
lopokban adott idő alatt megváltozó talajtulajdonság a másik oszlopban szereplő folyamatban már a megváltozott értékkel, vagy jellemezővel vesz részt.

$\mathrm{Az}$ 1. ábra második sorában a genetikai talajszintekre jellemző elsődleges folyamatok szerepelnek. A harmadik sorban a talaj genetikai szintjei, illetve a talajt körülvevő ökorendszer elemei közötti transzportfolyamatok szerepelnek. A negyedik sorban az oszlopra jellemző folyamatok időléptéke látható, az ötödik sorban pedig a folyamatmodellekkel elöre jelezhető, illetve a modellek által becsülhető talajjellemzők listája található, amelyek a modellezés céljától függően mérendőek és/vagy becsülhetőek.

$\mathrm{Az}$ 1. ábrán szereplő modellszerkezetben például a hőmérséklet hatása az egyes részfolyamatokra és azok összekapcsoltságára jól nyomon követhetö. A talajban a höáramlás kulcsfontosságú minden, a talajban végbemenő egyéb folyamatot tekintve (pl. a szervesanyag-lebomlás, vagy tápanyagfelvétel). A talaj hömérséklete a talajnak, mint közegnek a növényi növekedést szolgáló funkciója szempontjából is meghatározó. A talajtulajdonságokat a hőmérséklet különböző időléptékekben befolyásolja annak ellenére, hogy a hőmérsékletnek napi, vagy annál rövidebb időléptékű változása van. Modellezési szempontból a talajszelvényben végbemenő hötranszport felírható, és a talajrétegek változó hőmérséklete az ott végbemenő folyamatok kinetikájában tükrözödik. A talajfolyamatok összetett kapcsolatrendszere is megjelenik a modellezésnek ebben a formájában.

3. A modularitás, vagyis egyedi részekböl felépitettség. Ahhoz, hogy ez megvalósuljon, a részfolyamatokat leíró modellek idő- és térléptéke egymástól független kell, hogy legyen. Ezt a függetlenséget az is indokolja, hogy amennyiben a szakmai ismeretek egy adott részfolyamatot illetően bővülnek és a modellbe beépülnek, hatásuk nem jelenhet meg egy másik modellrész folyamataival ellentmondásban. A talaj genetikai fejlődését leíró szimulációs modell tehát, moduláris felépítésben működtethető. Például a 2. ábrán kilenc elsődleges elemi modell szerepel három elkülönülő (I-III) szinten. Az I. szinten az 1. ábrán bemutatott öt fő talajfolyamat-csoport szerepel. A II. szint az eseményeket rendezi össze időben és a futási eredményeket mutatja be a történések sorrendjében. A III. szint lehetőséget ad a modellezőnek arra, hogy megszabja a modellezési eredmények lekérdezésének módját, formáját és időléptékét.

A talajfejlődés modell tehát alapvetően modulárisan épülhet fel, és a részfolyamatok kölcsönhatása, összekapcsolása képez egy további, lényeges modellépítési feladatot. Bemutattuk, hogy az egyes talajtani részfolyamatok leírására specifikus modellek készíthetők, illetve állnak rendelkezésre. Ezek a részmodellek önálló modellként például a talaj fizikai, vagy kémiai folyamatainak leírására alkalmasak.

A következökben a talajtani folyamatmodellek jellemzőit, elvi megoldásait tekintjük át. Elsőként a talajfejlődést, mint a rendezettség növekedését az entrópia csökkenésével összekapcsoló hipotézist ismertetjük. Az entrópia-csökkenésre épülö talajfejlődési koncepció alapvetően ökológiai alapú, amely a talajt, mint a fejlödése során szintén az entrópia-csökkenést mutató ökológia rendszer egy részét, összetevőjét tekinti. 


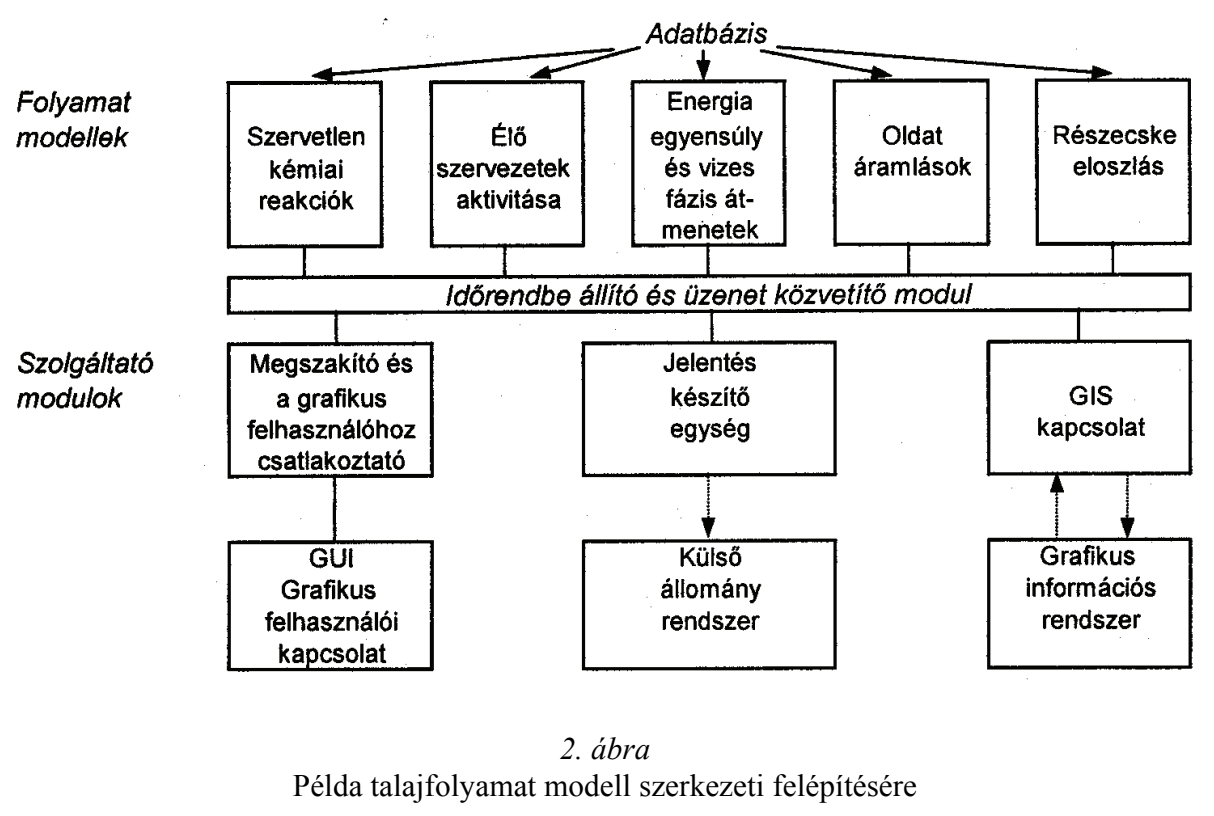

\section{Az entrópia fizikai-kémiai jelentéstartalma}

Az entrópia az anyagi rendszerek molekuláris rendezetlenségének, illetve állapotuk termodinamikai valószínűségének a mértéke. Extenzív mennyiség, vagyis egységes összetételü és változatlan állapotú rendszer entrópiája arányos anyagának mennyiségével. Mértékegysége $\mathrm{J} / \mathrm{K}\left(\frac{m^{2} \cdot k g}{s^{2} \cdot K}\right)$.

Az entrópiatétel a termodinamika II. Főtételéből következik és segítségével megadható az önként végbemenő folyamatok iránya. Elszigetelt, zárt rendszerben minden irreverzibilis folyamat az entrópia növekedésének irányában megy önként végbe. A termodinamikailag nyitott rendszerek környezetükkel höt és/vagy anyagot is cserélnek. $\mathrm{Ha}$ az entrópiatételt nyitott rendszerre alkalmazzuk, a vizsgált rendszert munkarendszernek nevezzük, és rendszerint hozzászámítjuk a környezetet is, mint hőforrást. Reverzibilis folyamat esetén az entrópiaváltozás nulla, az irreverzibilis folyamat pedig entrópianövekedéssel jár. Az entrópiatételből szükségszerűen csak a rendszer egészére érvényes nulla entrópiaváltozás, vagy az entrópianövekedés következik. A munkarendszer entrópiája csökkenhet is, ha azt a környezet entrópia növekedése egyenlíti ki. A rendszerben tehát entrópiacsökkenéssel is végbemehetnek önként reverzibilis és irreverzibilis folyamatok.

Az entrópiatétel statisztikus termodinamikai értelmezése szerint egy termodinamikai rendszerben csak olyan folyamatok mehetnek önként végbe, amelyekkel a rendszer az eredetinél nagyobb termodinamikai valószínüségi állapotba kerül. Annál nagyobb valamely rendszer termodinamikai valószínüsége, minél kisebb a rendszert alkotó részecskék anyagi és energetikai rendezettsége. Ebből következik, hogy a termodinami- 
kai folyamatok a rendezettség csökkenése irányában mennek önként végbe. Az entrópianövekedéssel járó, önként végbemenő folyamat közben a rendszer munkavégzésre fordítható energiája csökken, vagyis a rendszer hasznosítható energiája szétszóródik (disszipálódik), termikus energiává alakul.

Szintén a statisztikus termodinamika entrópiatételéből következik, hogy minden olyan folyamat, amely a molekulák mozgási lehetőségeit növeli (disszociáció) az entrópia növekedését idézi elő, az atomok, molekulák közötti kapcsolat megerősödése (asszociáció) viszont az entrópia csökkenésével jár.

A rendező folyamatokban az entrópia csökken, míg a szétszóró folyamatokban az entrópia nő.

\section{Entrópia csökkentő és növelő folyamatok a talaj-növény rendszerben}

A fotoszintézis olyan biológiai alapfolyamat, amelyben szén-dioxidból és vízből magasabban szervezett szénhidrát-molekula képződik. Az ezzel ellentétes légzési folyamatban a fotoszintézis során felépült szénhidrát-molekulából ismét víz és széndioxid keletkezik. A légzés a szétszóró, vagyis entrópia növelő folyamatok egyike, amelyet a hőenergia táplál.

A fotoszintézisnek és a légzésnek talajképződési szempontból is van jelentősége, hiszen arányuk szabja meg a talajba kerülő szerves anyag mennyiségét.

A fotoszintézis és a hozzá kapcsolódó asszimilációs rendező folyamat a növényi növekedésben is megvalósul oly módon, hogy az asszimilált anyagok szervekké, változatos szervi funkciókká (raktározó szár, raktározó gyökér, kapaszkodó szár stb.) alakulnak.

Az öregedés, mint szétszóró, entrópia növelő folyamat hajtóereje szintén a hőenergia egy sajátos formája, hiszen a növényi DNS-ben tárolt információ kontrollja alatt megy végbe. Talajképződési szempontból a növényi növekedésnek talán legfontosabb részfolyamata a gyökérnövekedés, amely által azok az ionok is megkötésre kerülnek, amelyek egyébként a szétszóró folyamatban a gyökérzónából kimosódnának.

A humuszképződés részben rendező, részben szétszóró folyamat, mert a talajba kerülő növényi anyagot a talajlakó állatok és a mikrobák $\mathrm{CO}_{2}$-re és más kis molekulákra bontják. A humuszanyagok két módon is a talajszelvény struktúrálásában, szerkezetének kialakításában játszanak fontos szerepet: egyszer a humuszképződés a talajszelvény képződésének a része, másrészt a humusz a talajaggregátum-képződés cementáló anyaga, és ezen módon is részt vesz a talajszelvény stabilizálásában.

A humuszlebomlás szétszóró, entrópia növelő folyamat, amely $\mathrm{CO}_{2}$-ot, $\mathrm{NH}_{4}$-ot és más kis molekulájú vegyületeket eredményez, továbbá a talajbiomassza életfolyamatainak a részét képezi.

A talajképződés fizikai folyamataiban a víz lényeges energiaközvetítő szerepet játszik. Például a magas légrétegekben kondenzálódó vízből a víz párolgására fordított energia felszabadul, amely onnan az ürbe kisugárzódik. A folyadékfázisban kondenzálódó víznek azután van potenciális, majd kinetikus energiája. A kinetikus energia nagy része a talajfelszínen szóródik szét, a maradék potenciális energia a hajtóereje a víz talajbani áramlásának. RUNGE (1973) a vízmozgást rendező és szétszóró folyamatnak is tartja, mert az egyrészt a talajképződést, másrészt a talajpusztulást (eróziót) is 
szolgálja. Az, hogy melyik folyamat válik dominánssá, attól függ, hogy a talajfelszínre érkező víz kinetikus energiája meghalad-e egy kritikus értéket (MORGAN, 1986). A kritikus energia értéke azonban talajfüggő. A talajból elpárolgó víz szintén része lehet rendező, entrópia csökkentő folyamatnak, pl. a réti és a szolonyeces réti talajok Bszintje periodikus átnedvesedése és kiszáradása révén a jellegzetes poliéderes-prizmás, illetve az oszlopos talajszerkezet-képződésének. A talajszerkezet-képződési folyamatban természetesen egyéb hatások (pl. a talajrészek közötti erőhatások) is szerepet játszanak, amelyek tárgyalásától itt eltekintünk.

A talaj-növény rendszerben sem egészében, sem az egyes részfolyamatokhoz kötötten az entrópianövekedés, vagy -csökkenés mértékét mennyiségileg nem tudjuk meghatározni (RUNGE, 1973). Ha valamilyen módon az egyes részfolyamatokat súlyoznánk, a folyamatok közötti kölcsönhatások figyelembevétele jelentene további nehézséget. A feladat nem egyensúlyi termodinamikai kezelése azonban a következökben ismertetésre kerülő lehetőségeket adja a rendszer entrópiaprodukciójának vizsgálatára.

\section{Indukált áramlás és entrópiatermelés}

A hajtóerő és az áramlás törvényszerüségei Ohm és Darcy törvényei alapján ismertek. A talaj-növény rendszerben azonban többféle hajtóerő és áramlás zajlik egymás mellett. Gyakorlatilag valamennyi eröhatás és áramlás összefügg. Az ilyen módon összefüggő áramlások leírása található KATCHALSKY és CURRAN (1967) közleményében. A konjugált (összekötött) áramlások leírására szolgáló egyenlet alapján megfogalmazható a hajtóerő és az áramlás az adott anyagra, illetve folyamatra. Az erő és áramlás szorzat dimenziója entrópiatermelés, vagy másképpen az egységnyi idő alatt végbemenő szabadenergia-csökkenés. Elektromos analógiát alkalmazva a jelenség megfelel annak a hőtermelésnek, amelyet egy vezetőn terjedő áram hoz létre elektromotoros erejével.

Amennyiben a rendszerben sikerül különválasztani a hajtóerőt és a létrehozott áramlást, a rendszer entrópiaváltozása az egyes részfolyamatok entrópiájának összegeként kezelhető. Ha egy hajtóerő többféle anyagáramlásra is hat, az erő megosztásával írható fel az entrópiatermelésben kifejtett hányad. Ennek a megosztásnak a részfolyamatokra történő szétosztása gyakorlatilag nem megvalósítható. Az elv alkalmazása a talaj-növény rendszerre azonban lehetővé teszi néhány termodinamikai következtetés levonását. Például azt, hogy ha egy termodinamikailag nyitott rendszert érni hagyunk, akkor annak entrópia termelése idővel csökkeni fog, míg végül minimumot ér el (KATCHALSKY \& CURRAN, 1967). Szerzők ebböl azt a következtetést vonták le, hogy ha egy konjugált erőhatás az adott áramlást akadályozza, az áramlás úgy változik, hogy csökkentse az akadályozó hatást, és a rendszer az eredeti állapotába térjen vissza. Ez a következtetés a növényökológiában ismert homeosztázis elvet, mint nyitott termodinamikai rendszersajátságot mutatja meg. Ebböl a felismerésböl az is következik, hogy egy perturbáció, azaz zavaró hatás növeli a rendszer entrópiatermelését.

A nyitott termodinamikai rendszer egyensúlyi állapota, és az élő szervezetek érési állapotig mutatott fejlődése analógiás folyamatsornak tekinthető. A minimális entrópiatermelés az életjelenségek evolúciójának egyik alapelve. Az élő szervezetek a zavaró hatás kiszürésére és egyensúlyi állapotuk fenntartására szabályozó mechanizmussal 
rendelkeznek. Ami igaz az egyedre, az igaz arra az ökológia rendszerre is, amelynek az egyed a tagja. Vagyis az ökológiai rendszer is fejlődésen, érésen keresztül jut el érett egyensúlyi állapotába. Az ökológiai rendszerre (ökorendszerre) is igaz, hogy a saját egyensúlyi állapotának a fenntartása mellett a zavaró hatások kiszürésére is „,örekszik".

A talaj kezdetben az ökológiai rendszer fejlődésének egyik korlátozó tényezőjét képezi, megszabva az ökorendszer érési útjának az irányát, majd részt vesz az érési folyamatban és maga is változások sorozatán megy keresztül.

Ha az ökorendszert zavaró hatás éri, a szabályozó mechanizmus - mint ahogy azt már láttuk -, a zavaró hatás megszüntetése és az egyensúlyi állapot fenntartása irányában hat. A talaj szintén részese ennek a folyamatnak. Felmerül azonban a kérdés, hogy a zavarásnak milyen hosszú ideig kell hatnia, hogy az új fejlődési korlátként jelenjen meg és új egyensúlyt eredményezzen. Amennyiben azonban a zavaró hatás katasztrofális, az ökorendszer nem képes magát új egyensúlyi állapot felé kormányozni.

Az előzőekben említett lehetőségekre egy ökológiai példa a következő: egyensúlyi ökológiai rendszer a klimax vegetáció. Magyarországon például a lombos erdő valamilyen formációja a hozzá tartozó erdőtalajjal az egyensúlyi ökorendszerek egyike. Nyilvánvaló, hogy erdővegetáció nélkül a lombos erdő ökorendszer talaja teljesen különböző lenne. Amennyiben a talajról az erdőt levágjuk és szántóföldi művelést alakítunk ki, az erdőtalaj tulajdonságai megváltoznak, szervesanyag-tartalma csökken, szerkezete degradálódik és entrópiája mindaddig nő, míg egy új, magasabb entrópiájú egyensúlyi állapotot nem ér el. A felhagyott szántóföldön az erdő csak hosszú idő után települne vissza, de minden valószínüség szerint regenerációja végbemenne, vagyis az erdősülési folyamat visszafordíthatónak, reverzibilisnek tekinthető. Az angliai Rothamsted Kísérleti Állomás hosszú idejü talajtani megfigyelésekkel rendelkezik, amelyek azt bizonyítják, hogy az eredeti vegetáció megváltozása nem jár együtt katasztrofális talajtani változásokkal. Ennek oka a talajok fokozatos megváltozása lehet. Megfigyelést végeztek egy olyan területen, amely évszázadokon keresztül mezőgazdasági müvelés alatt állt, majd a müvelés felhagyását követően 1883-tól visszaerdősült. Az 1964-ben visszaerdősült (AVERY \& KING, 1971), és a továbbra is szántóként használt talajok szelvényleírását (AVERY \& BULLOCK, 1969) és jellemzőit összehasonlítva a morfológiai különbség csupán kismértékünek látszott annak ellenére, hogy a visszaerdősült talaj évente $530 \mathrm{~kg}$ szénnel és $45 \mathrm{~kg}$ nitrogénnel többet kötött meg hektáronként, mint a mezőgazdasági terület talaja. Talán a legkifejezettebb különbség a feltalaj tömődöttségében volt kimutatható. A visszaerdősült talaj feltalajának kisebb tömődöttségét a földigiliszta aktivitás eredményezte, amely hiányzott a szántóterületről. A két terület talajának entrópiakülönbsége azonban éppúgy nem volt kimutatható, mint a szén és a nitrogén felhalmozódása (JENKINSON, 1971).

\section{Entrópia és a mezőgazdálkodás}

A természetes növénytakarójú ökorendszerekben a legeltetés és a szántóföldi müvelés zavarásnak, perturbációnak minősül. Az állandóan, évszázadok óta legeltetett, kaszált füves területeken azonban, ez az ismétlődően állandó perturbáció új egyensúlyi állapotot eredményezett. Ezen az alapon a hosszú ideje múvelt és trágyázott szántó 
perturbációja is állandónak tekinthető, és emiatt ott is új egyensúlyi állapot alakulhat ki.

A természetes ökorendszer egyik fontos jellemzője egyensúlyi állapotának állandósága, vagyis fenntarthatósága. Az állandó zavarással fenntartott mezőgazdasági rendszerek (legelők, kaszálók, szántók), mint láttuk szintén fenntarthatók, és energetikailag új egyensúlyi állapotot képviselnek. A természetes ökorendszerek fenntarthatóságára azonban minimális entrópiatermelés mellett kerül sor, míg a perturbáció révén fenntartott mezőgazdasági kultúrák esetében ez a feltétel annyiban változik, hogy az új entrópiaprodukció az adott feltételek mellett válik minimálissá, de értéke nagyobb a természetes ökoszisztémákénál. Amennyiben az entrópiatermelésbe a környezetkárosító kismolekulákat (pl. $\mathrm{CO}_{2}, \mathrm{~N}_{2} \mathrm{O}, \mathrm{NO}_{3}{ }^{-}$és $\mathrm{CH}_{4}$ ) is beleértjük ügyelnünk kell arra, hogy azok környezetkárosító mennyiségben ne keletkezhessenek. Amennyiben ez a feltétel teljesül, a mezőgazdasági használat is fenntarthatónak tekinthető.

$\mathrm{Az}$ entrópiatermelés alapján az organikus gazdálkodás fenntarthatóságának a megítélése azért nehezebb, mert ott a gyepek néhány év utáni feltörése a gazdálkodás része. Emiatt sem a gyep, sem a szántó nem juthat egyensúlyi állapotba, vagyis termodinamikai alapon az organikus gazdálkodás minősítése egyelőre nem egyértelmü. A trópusi vidékeken az organikus gazdálkodás gyepforgóját a katasztrofális erózió lehetőségének a csökkentésére alkalmazzák.

\section{Talajképződési folyamatok}

A talajképződés az anyakőzet mállási és biogén folyamataiként megy végbe adott éghajlati és emberi hatások alatt. A mállási és biogén talajfolyamatok eredményeként keletkező anyagok a talajszelvényben a vízáram révén oszlanak szét. A megoszlás térés időbeli eredményeként jön létre a talajok vertikális és horizontális rétegzettsége. A talajképződés lassú és hosszú időtávú folyamat. Az agyagkilúgzás eredményeként létrejövő agyagfelhalmozódási szint kialakulásának az idejét 10000 évre, míg a podzolosodás idejét legkevesebb 500 évre teszik.

A víz bármely formájára (csapadék, lefolyás, jégképződés és olvadás, kis- vagy nagyhozamú felszíni vízfolyás, tenger, talajvíz és talajnedvesség) vonatkozó vízáramlás hajtóereje a talajképződésnek is alapvető tényezője.

A talajképződés kémiai folyamatainak tárgyalásához a folyamatok térbeli kiterjedését, léptékét szükséges ismerni.

Egy adott folyamatot leíró modell mindig csupán egy meghatározott mérettartományra lehet érvényes. Ezért a modellalkotásnál, illetve a modell kiválasztásánál a modellezendő folyamat léptéke, érvényességi tartománya meghatározó.

A talajfolyamat modellek választékának ismertetése előtt a modellek általános típusait tekintjük át.

\section{Modellek és felosztásuk}

A modellt készítésének célja határolja be. Különbözőek a modellek aszerint, hogy kutatási, oktatási, kezelési, vagy szabályozási célra készültek. Két fó típusuk ismert: az analitikus és a numerikus modellek. 
Lehetséges a modelleket osztályozni aszerint, hogy mennyire matematizáltak (kvalitatív, kvantitatív modellek), amelybe nem csupán a számítógépi kódok, hanem az alkalmazott hipotézisek is beleértendők. Ezekre a vegyes determinisztikus és konceptuális modellekre érvényes a szakértői rendszerekben is alkalmazott megoldás, hogy a modell válasza nem csupán matematikai formulákon, azok megoldásán és a formulákban szereplő paraméterek megadásán nyugszik, hanem a modellbe épített szóbeli információkon, amelyek mint modell válaszok jelennek meg a kimeneten. A matematikai modellek az alkalmazott formula, a differenciálegyenlet analitikus megoldását jelentik, a megoldásban használt peremfeltételek és paraméterértékek esetén. Ekkor a modellkimenet a peremfeltételek és a paraméterek által meghatározott. Ezekkel a modellekkel a talajtanban használt paraméterek (talajt jellemző értékek) térbeli variabilitása és heterogenitása mértékének a modellezett folyamatra gyakorolt hatása elemezhető. Lehetséges azonban a matematikai modellek megoldását valószínüségi alapon is végezni, amikor is a modellkimenet nem egy meghatározott érték, hanem egy érték és a hozzá tartozó statisztikai valószínüség. A statisztikai valószínúséget is figyelembe vevő modellek a stochasztikus modellek.

Azok a vízforgalmat, talajvízforgalmat leíró modellek, amelyekben a csapadék eloszlása statisztikusan épül be, a két eddig ismertetett modelltípus között helyezkednek el. A matematikai modellek egy lehetséges felosztását mutatjuk be az alábbiakban AdDiscott és WAGENET (1985), ill. HoOSBEek és BRYANT (1992) nyomán:

1. Determinisztikus
a) Mechanisztikus
(általában sebesség paraméterekkel)
b) Müködési (funkcionális)
(általában kapacitív paraméterekkel)

2. Sztochasztikus

a) Mechanisztikus (véletlenszerüen kiválasztott eloszlási paraméterek)

b) Nem-mechanisztikus (sürüségfüggvény paraméterek)

Más szempontú felosztási lehetőségek:

Cél, Összetettség (komplexitás), Rugalmasság (flexibilitás), Átvihetőség (transzferabilitás)

Kvalitatív vagy kvantitatív jelleg

Hierarchikus felépítés szerint

Információs szintek szerint

A modell szerkezeti felépítése lehet bonyolult, vagy egyszerü; funkcionális, vagy mechanisztikus természetü. A funkcionális, vagy müködést leíró modellek általában leegyszerüsítik a folyamat leírását, csökkentik a bemenő adatmennyiséget és a müveleti időt azáltal, hogy empirikus egyenleteket, vagy közelítő (pl. regressziós) függvényeket alkalmaznak. A vízmozgást leíró müködési modell egyik gyakori típusát az ún. kapacitív modellek alkotják, amelyek statikus talajparaméter-értékekkel dolgoznak (telítési víztartalom, szántóföldi víztartalom, térfogattömeg stb.).

A mechanisztikus modellek azonban a modellezett folyamat mechanizmusának leírását azon a szinten tartalmazzák, ahogyan az aktuálisan ismert, és abba minden ismert részfolyamat is bekapcsolásra kerül. A mechanisztikus modellek éppen ezért bonyolultak és - tekintettel az alkalmazott egyenletek analitikus megoldásának lehetetlenségére - általában numerikus iterációs megoldással számítható ki az eredményük, 
amely megnöveli a számítási és a futási időt. A mechanisztikus modellek hipotézisellenőrzésre alkalmazottak, kevéssé ismert összefüggések feltárását segítik, amelyek miatt általában jóval bonyolultabbak a funkcionális modelleknél.

A modellek felosztásának egy további lehetősége a modellezés léptéke szerinti felosztás. HOOSBEEK és BRYANT (1992) a modelleket szerveződésük szintje szerint hierarchikus rendszerbe foglaló összeállítását mutatja be a 2. táblázat. Az egyes szervező-

$$
\text { 2. táblázat }
$$

A víz- és oldatmozgás modellezési léptékei, a modellek típusai és az alkalmazott mérési és becslési módszere (DELCOURT \& DELCOURT, 1988 alapján)

\begin{tabular}{|c|c|c|c|}
\hline $\begin{array}{l}\text { Ská- } \\
\text { la }\end{array}$ & Lépték & Modell-féleség & $\begin{array}{l}\text { Mérési és becslési } \\
\text { eljárások }\end{array}$ \\
\hline $\mathrm{i}+6$ & világ (Föld) & konceptuális & távérzékelés, éghajlat \\
\hline$i+5$ & kontinens & konceptuális & távérzékelés, éghajlat \\
\hline$i+4$ & ország, állam, tartomány & statisztikai modellek & légifotózás \\
\hline $\mathrm{i}+3$ & $\begin{array}{l}\text { talaj-régió } \\
\text { (összekapcsolt vízgyüjtők) }\end{array}$ & $\begin{array}{l}\text { hidrológiai modellek } \\
\text { tömegegyensúly modellek } \\
\text { (valószínüségi, statisztikus } \\
\text { determinisztikus/ müködési } \\
\text { modellek) }\end{array}$ & $\begin{array}{l}\text { geohidrológiai technikák } \\
\text { fuzzy clustering }\end{array}$ \\
\hline $\mathrm{i}+2$ & katéna, vízgyüjtő & $\begin{array}{l}\text { vízgyűjtő modellek } \\
\text { megosztott, vagy statisztikus } \\
\text { hidrológiai modellek } \\
\text { (determinisztikus és } \\
\text { sztochasztikus vegyes } \\
\text { modellek) }\end{array}$ & $\begin{array}{l}\text { geostatisztika, geohidro- } \\
\text { lógiai technikák (hidrográf, } \\
\text { vízkémia) }\end{array}$ \\
\hline $\mathrm{i}+1$ & $\begin{array}{l}\text { polipedon } \\
\text { (tábla) }\end{array}$ & $\begin{array}{l}\text { két- és háromdimenziós } \\
\text { oldalirányú áramlások } \\
\text { (determinisztikus múködési } \\
\text { modellek) }\end{array}$ & TDR, GPR, geostatisztika \\
\hline $\mathrm{i}$ & pedon & $\begin{array}{l}\text { tömegáramlás modellek } \\
\text { ismert változatosságú (i -1) mo- } \\
\text { dellek determinisztikus/müködést } \\
\text { leíró modellek) }\end{array}$ & TDR, neutron-szonda \\
\hline $\mathrm{i}-1$ & talajszelvény, réteg & $\begin{array}{l}\text { egy- és két dimenziós deter- } \\
\text { Minisztikus kimosódási modellek; } \\
\text { mintázat felismerés } \\
\text { (determinisztikus / müködést leíró } \\
\text { modellek) }\end{array}$ & $\begin{array}{l}\text { tenziométerek, } \\
\text { ellenállás blokkok }\end{array}$ \\
\hline $\mathrm{i}-2$ & $\begin{array}{l}\text { másodlagos szerkezeti } \\
\text { elemek } \\
\text { (pedek, aggregátumok) }\end{array}$ & $\begin{array}{l}\text { megkerülő áramlás (bypass flow) } \\
\text { makropórusok }\end{array}$ & $\begin{array}{l}\text { vékonyréteg metszet, } \\
\text { festési eljárás, } \\
\text { üvegszálas optika, } \\
\text { CT }\end{array}$ \\
\hline$i-3$ & $\begin{array}{l}\text { matrix szerkezet } \\
\text { (szemcsekölcsönhatások) }\end{array}$ & $\begin{array}{l}\text { áramlások a talajmatrixban } \\
\text { (determinisztikus / müködési) }\end{array}$ & $\begin{array}{l}\text { vékonyréteg technika } \\
\text { térbeliség, NMR }\end{array}$ \\
\hline $\mathrm{i}-4$ & $\begin{array}{l}\text { molekuláris kapcsolatok } \\
\text { (pórus/ szemcse) }\end{array}$ & $\begin{array}{l}\text { elekrokémiai modellezés } \\
\text { (determinisztikus/ múködési) }\end{array}$ & $\begin{array}{l}\text { elektronmikroszkópos } \\
\text { technika, oldatkémia }\end{array}$ \\
\hline
\end{tabular}

GPR: ground penetrating radar (talajnedvességmérési eljárás); TDR: time domain reflectometry (talajnedvesség-mérési eljárás); CT: computer-assisted tomography (felületemelző eljárás); NMR: nuclear magnetic resonance (hidrogénatom mennyiségét mérő eljárás) 
dési szintek modelljei a magasabb szerveződési szint alrendszer modelljeinek tekinthetők, illetve az alacsonyabb szint modelljei szintézisének.

A talajképződés modellezésének egy adott léptékben a reprezentatív, centrális egysége a pedon ( $i$-szint). A pedon az a minimális térfogatú, kiterjedésü talajdarab, amely az illető talaj valamennyi ismérvét hordozza. Ebből következik, hogy a pedonon az általa reprezentált talaj fizikai és kémiai jellemzői méréssel meghatározhatók és értelmezhetők. A pedon nem minden esetben a talajszelvényt jelenti, lehet annál kiterjedtebb, de szükebb is. Természetesen, a mérési módszerek különbözőségéből adódóan a fizikai és kémiai jellemzők között már ebben a léptékben is különbség lehetséges. A
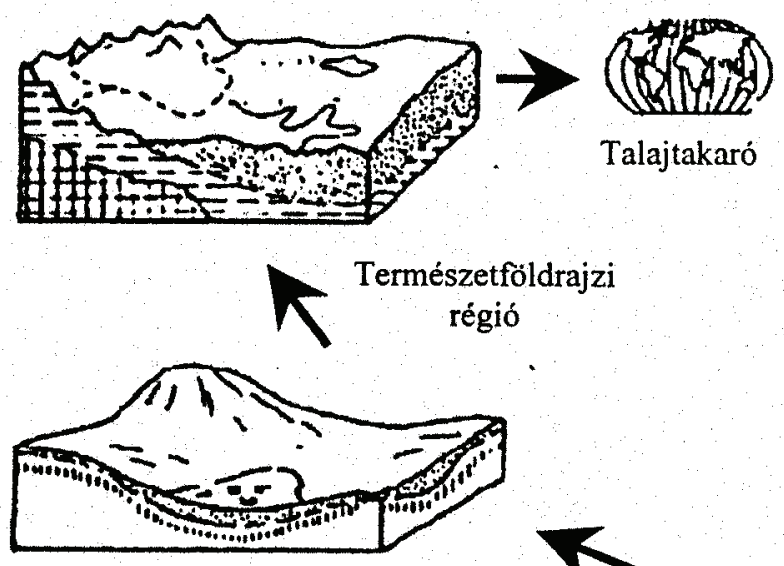

Talajsorozat vagy katéna
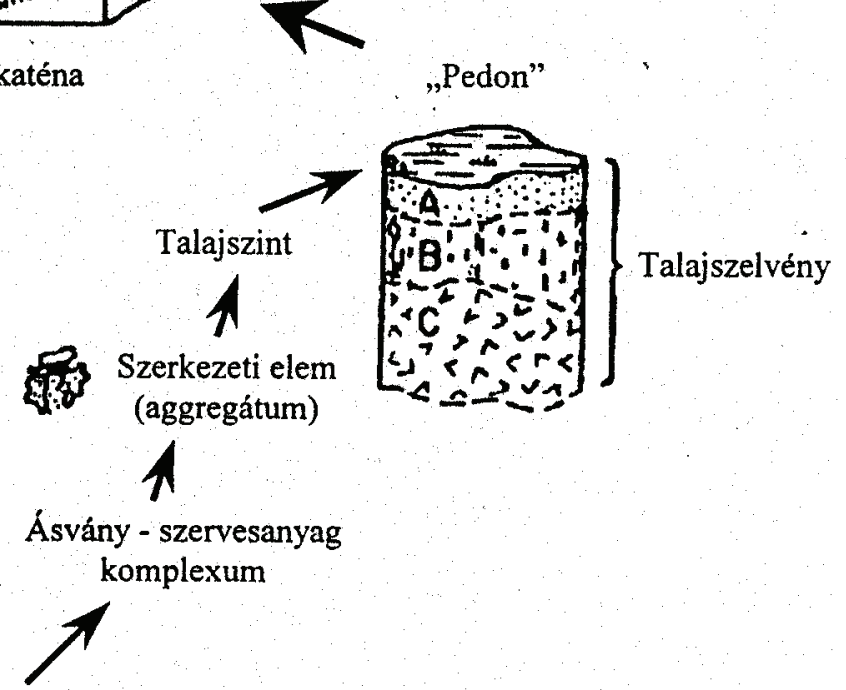

Molekuláris ásványi felépités 
pozitív $i$-szintek közül az $i+1$ lépték a polipedont jelenti, amelyben az $i$-szintü pedon értelmezésébe beleértjük annak területi változatosságát is. Természetesen ebben a léptékben is érvényre jut a kérdéses talajtulajdonság kimérésére, meghatározására használt mérési módszer általi meghatározottság. Az $i+2$ szint képviseli a katéna, vagy vízgyüjtő, az $i+3$ pedig a talajrégió léptéket. Negatív irányban az $i$-1szint képviseli a talajgenetikai, az $i-2$ a ped és az aggregátumok, az $i$-3 pedig a molekuláris kölcsönhatások szintjét. A talajalkotó komponensek, illetve a talajrendszerek egymásra épülését mutatjuk be a 3. ábrán, szemléltetve egyben a talajok komplexitásának növekedését is.

Valamennyi $i$-szinten a talajt leíró modellek háromdimenziósak (3D) kell, hogy legyenek. Azonban a talajban lejátszódó folyamatmodellek rendszerint csupán egy-, esetleg kétdimenziósak. A következőkben a különböző léptékben létező talajgenetikai és folyamatmodellek föbb ismérveit tekintjük át.

\section{A víz és a kémiai anyagok talajgenetikai szerepének modellezése}

A 2. táblázatban feltüntetett léptékekben történő modellezéshez szükséges az ott lejátszódó folyamatok megfogalmazása. A léptékhez illeszkedő mérési és a becslési módszerek megválasztása is szükséges, amelyre összeállítás szintén a 2. táblázatban található.

Az $i-4$, azaz a molekuláris skálán a víz és a kémiai anyagok kölcsönhatásainak leírása történik determinisztikus és mechanisztikus módon. A részecske-részecske interakcióknak, a duzzadás és a zsugorodás jelenségének, a víz és a vízben oldott anyagok anyagáramlásra gyakorolt hatásának a megértése a feladat ezen a skálán. Hagyományosan ezekben a tanulmányokban talajkémikusok, ásványtanosok, és fizikusok vesznek részt. A talajfolyamatok vizsgálatára ebben a mérettartományban szubmikroszkópos vizsgálati technikákat alkalmaznak, közöttük az NMR-t, a magmágneses rezonancia spektroszkópia technikát, amely a hidrogénatom oszcilláló elektromágneses térben mérhető energiaelnyelésével összefüggő rezonancia mérésén alapszik. A rezonanciagörbéről olvasható le a hidrogénatomok mennyisége.

A víz és a kémiai vegyületek talajoldat és a talajrészecske felülete közötti elmozdulásának a hajtóereje a kémiai potenciál rövid távolságú megváltozása, amelynek eredménye a víz és a vegyületek újra eloszlása (redisztribúció). Az ebben a léptékben megvalósuló áramlások (fluxusok) a talajképződési folyamatok lényeges elemei, amelyek a magasabb $i$-k szinten azután a talajképződés magyarázó okát és hajtóerejét is jelentik.

Az i-3 lépték a talajt felépítő szemcsék közötti pórusokban, a 0 és $-100 \mathrm{~cm}$ tenziójú nedvességpotenciál tartományban végbemenő mátrixáramlásokra vonatkozik. Ebben a léptékben a felületi feszültség és a kohéziós erők kombinációja a hajtóerő úgy, ahogy az i-4 szinten leírásra került. A talajmátrixban végbemenő telítetlen áramlás az, amelyben a kémiai anyagok újra eloszlása (redisztribúciója) végbemegy. Ezen a szinten azonban csupán az elemi talajegység (ped) jelenik meg, vagy egy homogén pórusszerkezetü, makropórusok nélküli, ped-nek nem tekinthető talajdarab. A vízvezetöképesség- és a víztartóképesség-függvényeket hat különböző talajszerkezeti típusra BOUMA és ANDERSON (1973) mutatták be. Újabban az NMR technikát használják a szük talajpórusokban végbemenő áramlások tanulmányozására. 
A másodlagos szerkezeti elemek alkotta pedre, vagy a nem ped talajdarabra jellemzőek a makropórusok, amelyek együttesen az $i$-2 léptéket alkotják. A makropórusos talajban végbemenő oldatáramlást kéthalmazú, vagy kétrekeszü (két kompartmentü) áramlásként tárgyalják általában. A kéthalmazú áramlás egyik összetevője a talajmátrix pórusaiban végbemenő, míg a másik a makropórus áramlás, amely a pedek között, és nem a peden belül zajlik. A makropórus olyan átméröjü pórus ill. csatorna, amelyben az áramlás hajtóereje a gravitációs potenciál. A szabadföldi és a laboratóriumi kísérleti tapasztalatok azt mutatják, hogy a kezdeti nedvességtartalom és a határfeltételi tényezök egyaránt alakítják a mátrixpórusokban, és a makropórusokban végbemenő áramlás arányát.

Az $i$-2 skálájú modellezés eredményei a tapasztalatok szerint nem egyértelműek. A festékek talajban történő terjedését leíró hidrológiai modellel azonban, ebben a léptékben nem sikerült összekapcsolni a talajmorfológiát és a talajhidrológiát. Az összekapcsolás csupán az $i-1$ léptékben sikerült. Az $i-2$ léptékben a makroporozitásnak, és a talajképződés során végbemenő kémiai áramlásoknak a kvantitatív összekapcsolása sem sikerült. A talajszerkezeti jellemzők azonban gyakran segítenek a kétfázisú áramlási mintázat jellemzésében. A makropórusok falán található vasbevonat a mátrixpórusokban történő oldatáramlás dominanciáját mutatja, amely során a redukált vas mozog a pedon külső felülete felé, ahol oxidálódik. A talajszerkezeti elemnek, a pedonnak a kifehéredett külseje a makropórusokban végbemenő domináns áramlás indikátora. A vas redukciója a szerkezeti elem élei mentén következik be, míg oxidációja a szerkezeti elem mátrixában történik akkor, amikor abban víz szivárog. Annak ellenére, hogy a folyamat világosan követhető, mechanizmusának modellel történő leírása még nem minden részletében értett.

Az i-1 lépték egyúttal a talajszelvény egy genetikai szintjét is jelenti, amely a talajgenetikai hierarchia talán leginkább kutatott eleme. A talajosztályozási rendszerek többsége az $i-1$ szinten a diagnosztikus szint jellemzöit vonatkoztatja (extrapolálja) az $i$, vagy még az a feletti szintre is. A jelentős genetikai szintek fizikai, kémiai és biológiai jellemzőinek funkcionális értelmezését interpolációra, míg a „mélységig”, vagy a „vastagságban” típusú kiterjesztéssel folytonos, regionális változóként is alkalmazzák (pl. BOUMA, 1989). Agyagos talajszint vízvezetőképességét a talajszerkezeti elemek közötti, morfológiai megfigyelésekböl megállapított áramlási nyomvonalak alapján számította ANDERSON és BOUMA (1973).

Az $i$-1 szinten történő mérési módszertan a reprezentatív elemi térfogat (REV) koncepció kidolgozásával, és azon a talaj hidrofizikai jellemzőinek mérésével jelentős fejlődésen ment át (LAUREN et al., 1988). A pedotranszfer függvények alkalmazásával a nem közvetlenül mért talajjellemzök is kiterjeszthetők a REV-re, és ezáltal modellezhetők. Amint a víz- és az oldatáramlás talajgenetikai összefüggéseinek meghatározása a cél, annak a vizsgálatához a szükséges REV meghatározása kell, hogy a mérést és a modellezést megelözze.

A REV koncepció értelmében a pedon az a háromdimenziós, megfelelően nagy méretü és kiterjedésú REV, amely az $i$ szinten tartalmazza a vizsgált talajszelvény rétegzettségét és a rétegek jellemzőinek variabilitását. A variabilitás ismerete ebben az esetben azt jelenti, hogy ismert a domináns talajréteg jellemző értéke, valamint annak varianciája is. A talajjellemzők tér- és időbeli változatosságának ismeretében lehetséges, 
hogy a víz- és az oldatmozgás, mint talajgenetikai részfolyamat kerüljön vizsgálat alá. Ennek érdekében a talajgenetikai vizsgálatokban a növényzetet, az időjárást és a talajvíz-dinamikát is a maguk tér- és idődinamikájával szükséges a talajgenetikai vizsgálatokban figyelembe venni (WAGENET et al., 1991).

A talajgenetikai folyamatok tér- és időléptéke a pedonra is vonatkoztatható. A pedonmodellek fajtái a determinisztikus/mechanikustól a statisztikus/konceptuálisig terjednek. Utóbbiak a mintázat felismerésen alapulnak, amelynek segítségével jelenítik meg például a festéknyomvonalak és a fémkiválások mintázatát (BOOTLINK \& BOUMA, 1991). A kimosódási modellek a pedon léptékben a víz- és a kémiai anyagtranszport, valamint az oldatkémia törvényein nyugszanak annak érdekében, hogy összekapcsolják a fizikai és a kémiai rendszert. A pedon léptékü kimosódási modellekben az időben változó határfeltételek használata lehetséges, mint amilyen a csapadék, a hőmérséklet, és a száradási-nedvesedési ciklusok. Ezek a lehetőségek a szabadföldi feltételek jobb leképezését nyújtják (HUTSON \& WAGENET, 1992). Mindez lehetőséget ad a modellérzékenység vizsgálata mellett a talajfolyamatokról, és folyamat-együttesekről alkotott, és a modellbe épített hipotézisek tesztelésére is.

A dinamikus szimulációs modellek nem új keletüek és igen sokfélék. A legtöbbjük kvantitatív, de érvényességük behatárolt. Talán leginkább arra alkalmas eszközök, hogy egy $i$-k szintü eredményt $i-1$, vagy $i+1$ szintre képezzék le. Ezt sok más típusú modell is tudja. Például KIRKBY (1985) egy matematikai modellt készített a talajszelvény-fejlődés leírására az $i-1$ szinten, amely mállási-, szervesanyag- és ásványianyag- szelvényeket eredményezett, az átszivárgás, egyensúlyi oldatok, kimosódás, iondiffúzió, szerves keveredés, lombhullás, szervesanyag-lebomlás és mechanikai lepusztulás eredményeként. A modell a helyben maradó anyagmennyiség alapján számítja a hiányzó anyagmennyiséget, vagyis a málladék (w) képződését a következő összefüggéssel:

$$
\mathrm{w}(\mathrm{z})=\int_{\mathrm{z}=0}^{\infty}(1-\mathrm{p}) \mathrm{dz}
$$

ahol: $z$ a felszíntől mért függőleges távolság, $p$ nem mállott, vagy maradó talajrész.

A z mélység alá történő elfolyás, a maximális beszivárgási mélység, valamint a mállás a hidrológiai jellemzők alapján kerül számításra. Ez a megoldás fígyelmen kívül hagyja az agyag fizikai áttelepülését, komplexek képződését, kémiai átalakulását, az ionkicserélődést és az adszorpciót. Az oldatkémiai számítás a szilárd fázissal mutatott egyensúlyon alapszik, ami nem mindig teljesül. A használt hipotézisek, egyszerüsítések és elhanyagolások miatt a modell csupán korlátozott érvényességü. Értékes azonban a talajszelvények, valamint a talajszelvény és a szelvényt körülvevő táj összekapcsolásában. Az egyszerüsítések ellenére tehát összekapcsolja a genetikai szintet $(i-1)$ a pedonnal $(i)$, vagy nagyobb területtel $(i+1)$.

A pedon szintű modellek választéka is nagy. Különbözőségük oka az, hogy eltérö helyzetekre kidolgozottak. Általában funkcionálisak és félkvantitatívak (pl. LEVINE \& CiOlKOSZ, 1986; MAYER, 1985; CHADWICK et al., 1990). Chadwick a talajképződés tömegegyensúlyának elvére épülő modellje a mállás és a talajgenetika hosszú idejü kapcsolatát elemzi. Az anyagmegmaradás elvét kifejező tömegegyensúlyi és térfogatváltozási egyenletek kombinációját alkalmazza a jól ismert szelektív extrakciós és a 
részecskeméret szeparációs folyamatokkal kombináltan, amikor is egy tengerparti homok erdőtalajjá (Alfisol) alakulását elemzi. Ezek a modellek szintén a víz és a kémiai anyagok áramlásának mennyiségi becslésén alapulnak, amelyek a talajgenetikai folyamatok megértését szolgálják. Azonban ezek a folyamatok a pedon szintjén még nem kellően ismertek és megértésük az i-1 szintủ ismeretek bővülésétől várható. Elöre mutatóak azonban a modell bemenő adatait és működési tesztjét szolgáló mérési eljárások, amelyek ismételhetők és gazdaságosan kivitelezhetők. Ilyen mérési eljárásokat ad a TDR technika, a neutron szonda és az automatizált tenziométeres eljárás.

$\mathrm{Az} i+1$, vagy a polipedon szint már tábla lépték. A polipedon szint a talajgenetikai folyamatok oldalirányú kiterjesztésére ad lehetöséget. Ezzel már lehetöség van két- és háromdimenziójú modellek alkalmazására, amikor is a kimosódás mellett az oldalirányú elfolyás, az erózió, valamint a felszín alatti elfolyás és a talajvízáramlás is figyelembe vehető. A léptékben a térbeli változatosság jelentősége nagymértékben megnő és azzal párhuzamosan a víz- és a kémiai anyagáramlás determinisztikus megoldásai, mint a talajfejlődést mutató indikátorok jelentősége gyengül. Modellezéstechnikailag ezt úgy valósítják meg, hogy a determinisztikus folyamatokat a Monte-Carlo szimulációs technika alkalmazásával sztochasztikus módon veszik figyelembe (pl. WAGENET et al., 1991; FInKE \& STEIN, 1993).

A tábla lépték már szükségessé teszi a modellezéshez a talaj és a környezeti adatok, jellemzők együttes és térbelileg értelmezhető mérését. Ebből következik, hogy a tábla szinten $(i+1)$ a geostatisztika és az idősorelemzés fontos és szükséges eszközzé válik. A tábla szintü feladatok egy másik megoldási lehetőségét a tábla mért pontjaira végzett szimulációs eredmények térbeli, valószínüségi alapú kiterjesztése jelenti (FINKE \& STEIN, 1993).

A katéna, vagy vízgyüjtő skála $(i+2)$ a víz- és a kémiai anyagok áramlásának és azok talajgenetikai hatásainak a táj léptékủ ismeretét teszi szükségessé (pl. RicHARDSON et al., 1992). Ezen a szinten a mechanisztikus és determinisztikus modellek használhatóak miután a térbeli mintázat a talajszelvényt alkotó genetikai szintekre (i-1) és oldalirányú kiterjesztésükre már megtörtént. Ezt követően a geostatisztika interpolációs módszerei alkalmazhatóak, de azok is lehetöleg homogén területekre. A modellek bemenő adatait ekkor a genetikai szintekre méréssel, vagy becsléssel szükséges felvenni (WÖSTEN et al., 1990).

A pozitív i szinteken végzett modellezésnek azonban nemcsak talajgenetikai okai és kimenetei lehetnek, hanem az, hogy az ökológia történései, törvényszerüségei a polipedon, vagy katéna léptékben értelmezhetők. Gyakori, hogy az ökológiai modellek legkevésbé kvantifikált, fekete dobozként kezelt eleme éppen a talaj, mint környezeti elem. Szükséges éppen ezért az ökológiai modellekbe integrált kvantitatív-mechanisztikus meteorológiai, biológiai és hidrológiai modellek közé valamely talajmodellt is bevenni.

A kvantitatív-mechanisztikus talajgenetikai történéseket leíró talajmodell ökológiai modellbe integrálása segítheti a talaj, mint környezet ökológiai hatásainak jobb megértését is. Az ökológiai léptékben (tér- és időskálán) változó talajkörnyezet ökológiai szerepének kutatásában és oktatásában fontos szerepet kaphat ez a próbálkozás. MARION és munkatársai (1985) regionális léptékü, a talajfejlődést sivatagi talajok mészdinamikáján keresztül vizsgáló modellje (CALDEP) tekinthető egy ökológiai lép- 
tékben megvalósított példaként. A CALDEP-modell különböző tudományterületek (statisztika, meteorológia, talajfizika, talajkémia, talajbiológia stb.) eredményeit integrálja. A modellnek a jelenlegi és három pleisztocén időjárási változattal végzett érzékenységvizsgálatai a talajfejlődés következő változókra vonatkozó érzékenységét mutatták: a viharok gyakorisága, a talaj vízkapacitása és a $\mathrm{CO}_{2}$ parciális nyomásának biológiai kontrollja.

Az $i+3$ skálán, vagyis az egymással kapcsolt, kölcsönhatásban álló vízgyüjtők szintjén a víz és a kémiai anyagok transzportját leíró mechanikus és determinisztikus modellek már nem alkalmazhatóak, helyettük a funkcionális és statisztikus megközelítések kerülnek előtérbe, amelyekben összevont, csoportváltózókat használnak. Ennek oka a léptékből adódik, hiszen a kilométeres léptékben egy-egy változó varianciája megnő, amelynek csökkentését szolgálja az összevont változók alkalmazása. Már a múlt században, és a század kezdetén használták ezt a koncepciót felszíni lefolyás, erózió és kisvízfolyás leírására. Táj léptékben az összevont változójú modellezést az ökológusok mind a mai napig alkalmazzák.

A Delcourt és Delcourt (1988) által készített táj léptékü ökológiai tér- és időfelosztás (2. táblázat), alapján látható, hogy a talajképződés mikroléptékü folyamat az olyan felszínalaktani folyamatokkal egyetemben, mint a talajfolyás, homokdombok mozgása, felszíni bemélyedés, folyami- és szélhordta üledékképződés. Ebben a táj léptékü felosztásban a talajképződés túlságosan nagyléptékü folyamatokhoz kapcsoltan jelenik meg. A hangsúly a tájléptékü mozaikok átrendeződésére irányul. A talajképződés megjelenése sokkal inkább holisztikus, mint folyamat orientált. Az alkalmazott szemlélet a százéves talajjellemzési, térképezési szemlélethez, nem pedig a mai folyamatszemléletű megközelítéshez áll közel.

Az i+4 lépték a politikai határokra sokkal inkább vonatkozik, mint a természetes határokra (megye, ország stb). Ebben a léptékben föként a statisztikai megközelítés használatos. A területre jellemző adatbázisokat GIS-rendszerben és statisztikai módszerekkel kezelik. A víz és a kémiai anyagok áramlása, áramlás-intenzitása ebben a léptékben nem jelenik meg. A térképezés a méretarányhoz illeszkedő jellemzőkre (pl. folyóvízi üledékek, szélhordta üledékek) megjelenítésére vonatkozik általában. A determinisztikus modellek ebben a léptékben nem a talajfolyamatokra, hanem a szabályozási és kezelési kérdések vizsgálatára szolgálnak. Az alkalmazott determinisztikus modellek annak ellenére kerülnek ebben a lépékben alkalmazásra, hogy más skálára készültek. A skála különbségből adódó kötöttségeket nem veszik figyelembe, hiszen azok hatása a modellezett eredményekre nem ismert.

A kontinentális $(i+5)$ és a globális $(i+6)$ léptékben alkalmazott modellek már kivétel nélkül az ún. konceptuális modellek. Talajtanilag ezekben a léptékekben talajgenetikai típusok és talajsorozatok jelennek meg. A víz- és a kémiai anyagtranszportot és intenzitást nem önmagukban, hanem hatásuk eredményében veszik figyelembe. Az anyakőzetre jellemző diagnosztikus szintek megléte vagy hiánya, a biológiai aktivitás mértéke, a klímahatás erőssége, mint differenciáló tényezők kerülnek felhasználásra a terület talajainak térszíni pozíciójával, a geohidrológiai-, hőmérsékleti- és csapadékviszonyokkal mutatott kapcsolat értékelésében. Ebben a táj léptékben értékelhető továbbá az emberi tevékenység hatása is a talajképződésre. A teljesség igénye nélkül ké- 


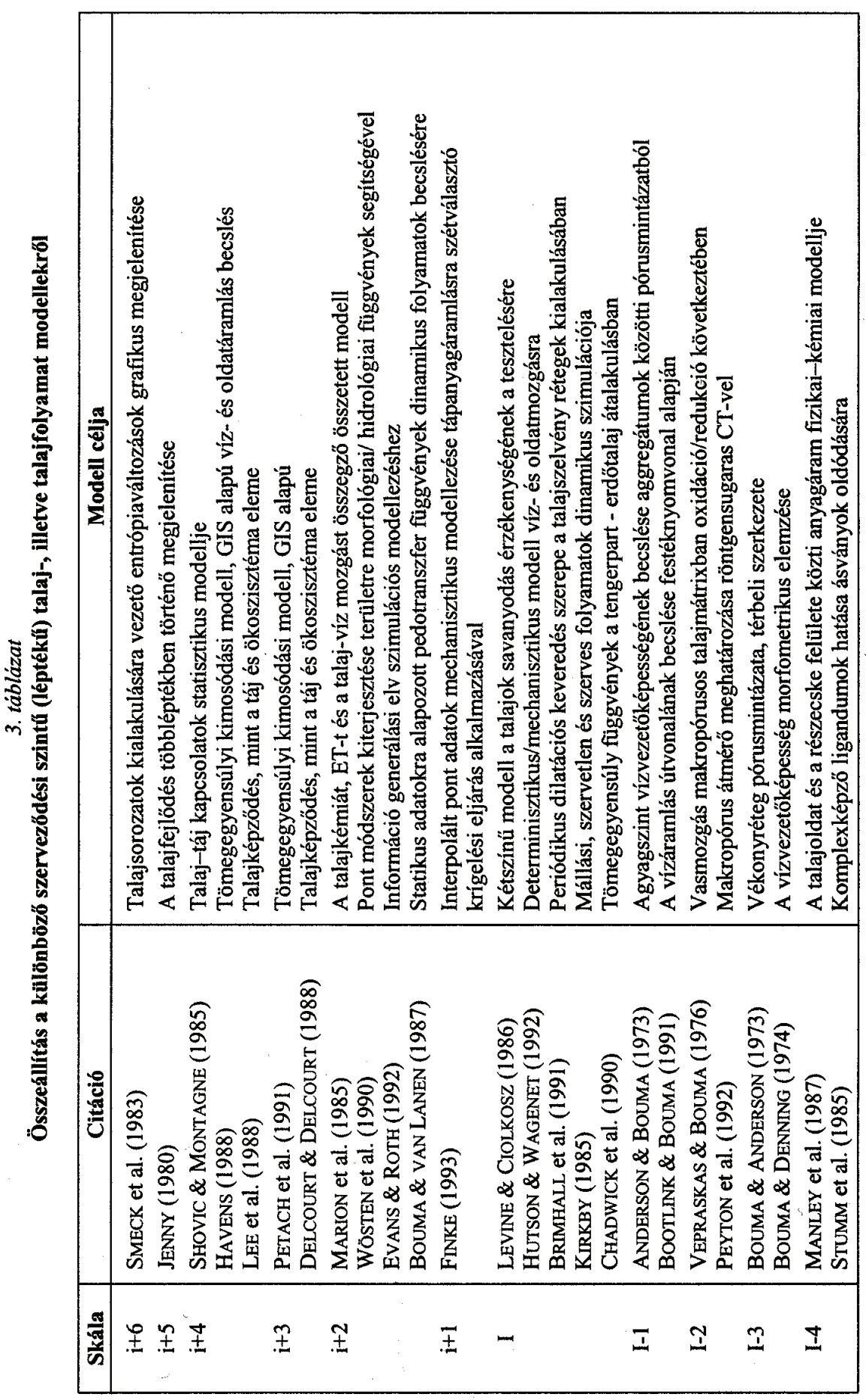


szített, az áttekintést segítő, irodalomból kigyüjtött modell-összeállítást mutatunk be az egyes szerveződési szintekre a 3. táblázatban.

\section{Kapcsolat a léptékek között}

Az előzőekben említett léptékek mindegyikéhez egy meghatározott idő- és térskála tartozik. Emiatt nem tanácsos egy adott léptékre kidolgozott modellt más tér- és időléptékben alkalmazni. Konkrétan például a pedon léptékü kimosódás modell nem alkalmazható vízgyüjtőre oly módon, hogy a pedon léptékű modell eredményét a térléptékkülönbség kiküszöbölése érdekében a megfelelő konstanssal fölszorozzuk. Ahhoz, hogy a léptékváltás lehetősége a különböző skálájú problémák között meglegyen, előzőleg koncepcionálisan szükséges mérlegelni azt, hogy lehetséges-e a skálák között kapcsolatot találni.

Egy adott $i$ szintre kidolgozott szimulációs modell az alacsonyabb $i$ szintekre érvényes törvényszerüségekböl azokat tartalmazza, amelyek lényegesek, de értelemszerüen azokat nem, amelyek lényegtelenek. Például a mechanisztikus modellekben az anyagáramlás az alacsonyabb $i$ szinteken a vegyületet alkotó elemek közötti molekuláris kölcsönhatásokon alapszik, magasabb $i$ szinten azonban, a vízmozgás már a vízpotenciálviszonyok függvényeként jelenik meg. Még magasabb $i$ szinten pedig már csak a következményként lezajló nedvességtartalom változásaként.

Jelenleg a talajban lejátszódó folyamatok különböző léptéken megjelenő eredményeit tekintve a megismerés szakaszában járunk. Például a szimulációs modell technikával vizsgálható, hogy a talajfejlődés évszázados léptékü folyamata hogyan függ az éves klíma és hidrológia periodikusságától, és mindebbe hogyan illeszkedik a víz- és a kémiai anyagmozgás. Ahhoz pedig, hogy a talajféleségek kialakulásában a transzportfolyamatok szerepe, illetve ezek térléptéke leírható legyen még további ismeretek szükségesek.

\section{A talajuáltozatosság hatása modellezési eredményekre}

SPOSITO és REGINATO (1992) megfogalmazása szerint a talajtan az a földtudomány, amely a talajképződési tényezőket és folyamatokat (mint a talajok minősége, kiterjedése, eloszlása, térbeli változatossága) mennyiségileg elemzi a mikroszkópikustól a makroszkópikusig terjedő skálán. A térbeli változatosság a talajképződés kőzettani, klimatikus, biológiai és felszínalaktani feltételein keresztül egészen a földtörténeti időig terjedő folyamatai által alakított. A talajtan müvelői már korán felismerték, hogy a térbeli változatosság tárgykörük egyik központi kérdésköre, azonban azon igyekeztek, hogy beillesszék azt a földértékelési, a kockázatbecslési, a környezetvédelmi és a mezőgazdaságon kívüli értelmezésekbe.

A magasabb térszínek talajai összefüggő láncfolyamatokon keresztül kapcsolódnak egységes rendszerré és hatást gyakorolnak a szomszédos alacsonyabb térszínek talajaira is. Ennek oka a talajképződés hajtóerejeként müködő energia- és anyagáramlás, amely háromdimenziós talaj-, illetve földfelszíni képleteket eredményez. A háromdimenziós talajmodellek építésére új lehetőség a „virtuális valóság modellezési nyelv” 
(GRUNWALD et al., 2000), amely pedon, katéna, vízgyüjtő és talajrégió léptékben a talajok összetett, háromdimenziós térbeli mintázatának a megjelenítésére szolgál.

A talajtani modellépítés fejlődése maga után vonja a talajok térbeli variabilitásáról alkotott nézetek fejlődését, valamint azt, hogy a legújabb ismereteket magukba foglaló tudásbázis jöjjön létre. A tudásbázis építése során alakulhat ki a térbeli változatosság törvényszerüségeinek és jelentéstartalmának a talaj összetevőire (minta, genetikai szint), a talajcsoportra, az egész elemére (toposzekvensz, katéna), illetve a talajtakaróra vonatkozó felismerése.

Maga a talajváltozatosság valamely talajtulajdonság tér- és időbeli megváltozását jelenti. A talajtanosok feladata, hogy megadják a modellépítőknek a változatosság nagyságát, formáját és mintázatát. A nehézséget az jelenti, hogy a talaj folytonosan létező objektum, tulajdonságai nem egyedi jellegűek, több tulajdonság időben változó, több pedig idő- és helyfüggő. Vagyis a talaj közegének tulajdonságai vízszintes és függőleges irányban is különböznek (vagyis anizotropok). A következőkben - modellezési szempontból - a talajváltozatosság milyenségét, mértékét, formáit és eredetét tekintjük át.

\section{A talajváltozatosság mértéke és eredete}

A talajok változatossága két tág kategóriába sorolható: a rendszeres (strukturált), ill. a véletlenszerü (strukturálatlan, ismeretlen ok miatti). A rendszeres változatosság a talaj tulajdonságainak fokozatos, vagy jellegzetes földrajzi, felszínalaktani, a talajképző tényezők közötti kölcsönhatások miatti változása (WILDING \& DREES, 1983). A strukturált változatosság a szubmikroszkopikustól a mega léptékig előfordul. A talajtanos számára a strukturált változatosság teszi lehetővé a talajok felosztását a talajtérképezési egységek, tájföldrajzi elemek szerint (kiemelkedésen, kiugró részen, a lejtő tetején, a lejtő alján stb. előforduló kategóriák). A nagyléptékü strukturált változatosság mértéke nagyobb lehet, mint a kisléptéküé. Példa erre a gilgai talajokra jellemző duzzadás-zsugorodás jelensége, amelynek következménye a felszín és az altalaj kémiájának és biológiai jellemzőinek méteres, vagy még annál rövidebb távolságon belüli megváltozása.

Még finomabb skálájú a szerves vagy szervetlen talajalkotók strukturált szerveződése, mint a pórusok felületét bevonó agyaghártyák, az oxihidrátok zonációja, és a vízvezető pórusokban a karbonátok és az oldható sók koncentrációja (WILDING \& HALLMARK, 1984). A gyökerek mentén a mikroszervezetek, valamint az aggregátok közötti felületeken lévő agyagbevonat strukturáltan szervezett (SPOSITO \& REGINATO, 1992). Eloszlásmintázatuk a vízáram, a diffúzió, a megkötődés és a mikrobiológiai kolonizáció folyamatait tükrözik mikron-, illetve szubmikron léptékben.

A véletlenszerü talajváltozatosságot a kőzet, a hidrológia, a mállási intenzitás, a biológiai aktivitás, az erózió és hordaléklerakódás, a talajmüvelés időleges hatása, a mintavétel és az elemzés hibája alakítja ki. Az említett hatások megjelennek a strukturált változatosságban is, azonban hatásuk általában finomabb annál, hogy azt elfedje.

A talajtani leírás célja éppen a talajra jellemző változatosság felosztása kisebb változatosságú (homogénebb) elemekre olyan módon, hogy a módszeres (szisztematikus) hiba a lehető legkisebb legyen. A talajtérképezési egységekben azonban, ennek ellenére jelentős változatosság marad. Egy felmérő elemzés azt mutatta, hogy a térképen feltüntetett talajféleség általában csupán $40 \%$-tól $50 \%$-ig fedi le a terület talajféleségeit, esetenként ez az arány azonban csupán $20 \%$. Ennek ellenére a térképezési 
egységek értelmezési ereje 50 \%-tól $85 \%$-ig terjed, 80 \%-os valószínüség esetén (MOKMA, 1987; NorDT et al., 1991).

Az amerikai talajfelvételezési előírás szerint úgy kell a talajtérképezési egységeket megalkotni, hogy az azokba besorolt talajok $75 \%$-ban feleljenek meg a talajtani leírásnak (Soil Survey Staff, 1983).

\section{4. táblázat}

Talajtulajdonságok csoportosítása változatosságuk szerint

\begin{tabular}{|c|c|c|c|}
\hline \multirow{2}{*}{ Talajtulajdonságok } & \multicolumn{2}{|c|}{ CV \% } & \multirow{2}{*}{$\begin{array}{c}\text { Talajváltozatosság } \\
\text { mértéke }\end{array}$} \\
\hline & Átlag & Tartomány & \\
\hline $\begin{array}{l}\text { Térfogattömeg } \\
\text { Szín (hue) } \\
\text { Szín érték (value) } \\
\text { pH } \\
\text { Plaszticitási határ }\end{array}$ & $\begin{array}{c}7 \\
9 \\
10 \\
10 \\
15\end{array}$ & $\begin{array}{l}5-13 \\
2-20 \\
4-12 \\
5-15 \\
5-28\end{array}$ & $\begin{array}{l}\text { Kevéssé } \\
\text { változatos }\end{array}$ \\
\hline $\begin{array}{l}\text { Folyási határ } \\
\text { A szint vastagsága } \\
\text { Szabadföldi vízkapacitás } \\
\text { Bázistelítettség } \\
\text { Homoktartalom } \\
\text { Mésztartalom } \\
\text { Szín (chroma) } \\
\text { Mésztartalom mélysége } \\
\text { Kicserélhető kationtartalom (CEC) }\end{array}$ & $\begin{array}{l}17 \\
18 \\
25 \\
25 \\
25 \\
28 \\
28 \\
30 \\
32\end{array}$ & $\begin{array}{c}8-31 \\
8-31 \\
10-31 \\
17-33 \\
8-46 \\
10-61 \\
20-30 \\
15-50 \\
20-49 \\
20-40 \\
\end{array}$ & $\begin{array}{l}\text { Mérsékelten } \\
\text { változatos }\end{array}$ \\
\hline $\begin{array}{l}\text { Kiválások mélysége } \\
\text { Szervesanyag tartalom } \\
\text { Plaszticitási index } \\
\text { Talajvastagság } \\
\text { Kicserélhető } \mathrm{Ca} \\
\text { Kicserélhető } \mathrm{K} \\
\text { Kicserélhető Mg } \\
\text { Vízoldható sótartalom } \\
\text { Vízvezetőképesség }\end{array}$ & $\begin{array}{l}35 \\
39 \\
41 \\
43 \\
48 \\
57 \\
58 \\
48 \\
75\end{array}$ & $\begin{array}{c}20-50 \\
20-61 \\
20-63 \\
25-58 \\
30-73 \\
7-160 \\
31-121 \\
- \\
13-150\end{array}$ & Változatos \\
\hline
\end{tabular}

\section{A talajtulajdonságok változatosságának a mértéke}

A talajszelvény-leírók és a modellalkalmazók egyaránt szeretnék ismerni a talajtulajdonságok változatosságának legalább a viszonylagos mértékét, nagyságrendjét. A 4. táblázatban olyan azonos talajtípus, azonos genetikai színtjeiből vett minták átlagértéke és szórása található, amelyek azonos besorolású térképezési egységbe tartoznak (UPCHURCH et al., 1988). A 4. táblázatban bemutatott átlagértékek és variációs együtthatók (CV) értelmezésében a következők átgondolása segít: 
- A talaj mélyebb rétegeinek tulajdonságaira adható becslés valóságtartalma a mélységgel csökken, minthogy a talajleírások maximális mélysége általában kisebb, mint 2 méter.

- Az időben állandó talajjellemzők (mint a szemcseösszetétel, az ásványi összetétel, a talajmélység, a szín) kisebb szórásúak, mint a jóval dinamikusabban változó nedvességtartalomé, vízvezetőképességé, redox állapoté, sótartalomé, biológiai aktivitásé, kicserélhető kationtartalomé, vagy a szervesanyag-tartalomé.

- A talajtulajdonság szórása függ az anyakőzettől. Az anyakőzet minősége szerint a következő növekvő sorrendbe rendezhető: lösz < tillit < szélhordta üledék < mélységi, magmás- és tektonikus kőzetek < erösen kevert anyagok.

- azon talajtulajdonságok, amelyeket egy standardhoz viszonyítva határoznak meg (pl. mechanikai összetétel, pH, szín stb.) kisebb szórásúak, mint a minőségileg besoroltak (pl. talajszerkezet, konzisztencia, porozitás, begyökerezettség stb.). Egy mintavételi helyen, illetve annak 1-2 m-es környezetében az állandó talajtulajdonságok CV-je 5-10\%, a dinamikus változóké 10-20\% közötti. A CV szélsőséges esetben 35\%-ig is terjedhet (WILDING \& DREES, 1983).

A laboratóriumi mérések elfogadott hibahatára $\mathrm{CV}=5 \%$-ig terjed. A 4. ábrán a mintamérettől függő relatív szórás látható.

\section{A talajuáltozatosság a modellezésben}

A térbeli változatosság modellezésben történő figyelembe vétele szakterületenként nagymértékben különböző és függ a modell természetétől is. A talajtani modellek többsége nem alkalmas hibaelemzésre. Ennek oka, hogy a modellkészítők a hibaelemzést a

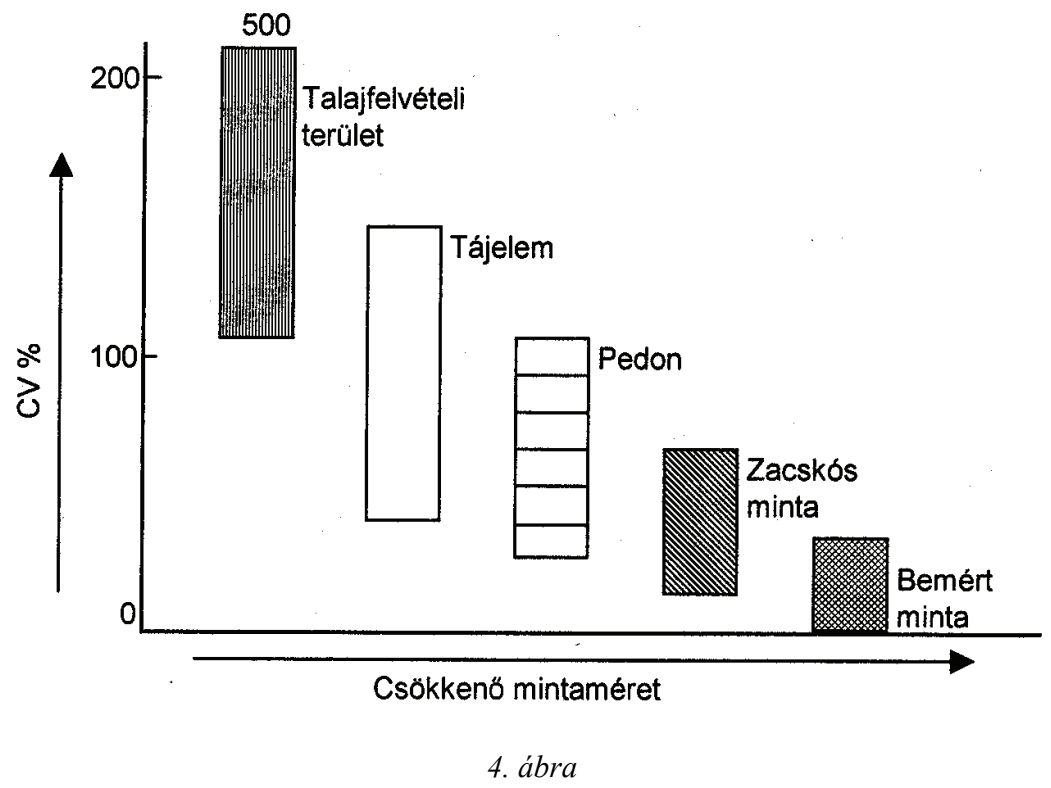

Talajtulajdonságok relatív változatossága a mintaméret függvényében 
modellezett rendszer túlontúl összetett volta miatt értelmetlennek látják (HOFFMAN, 1991).

A talajtérképen a talajok térbeli változatossága a talajfoltok lehatárolásával kerül kifejezésre, megjelenítésre. A talajfolthatár megrajzolását reprezentatív talajszelvények felhasználásával végzik azzal a feltételezéssel, hogy a megállapított folthatár egyben kijelöli a térbeli variabilitás mintázatot is. Az előző feltételezés azonban nem tartható, hiszen számottevő változatosság marad a körülhatárolt talajfolton belül. Az sem mindegy, hogy a változatosságot mely talajtulajdonságra vizsgáljuk, hiszen a korábbiak alapján látható, hogy az agyag-, szervesanyag-tartalom, vagy a térfogattömeg szórása jelentősen eltér a különböző talajfoltokban. Ez a megállapítás azonban nem minden talajtulajdonságra érvényes. Egy hollandiai talajsorozatra számított vízszolgáltató kapacitás szórását lényegesen kisebbnek találták az alapadatok szórásánál, amelyek a térképen szerepeltek (WÖSTEN et al., 1985). Az eredeti talajtérképen 350 talajfolt szerepelt, míg a számított vízszolgáltató kapacitás 100 térképezési egységet eredményezett. Ebből az következik, hogy a térbeli változatosság a talajtanban jelentősen különbözik aszerint, hogy alaptulajdonságról vagy funkcionális jellemzőről (pl a vízszolgáltató kapacitás) van szó.

\section{Térbeli változatosság a térképezési egységen belül}

A „Hogyan is kezelhető a talajfolton belüli változatosság?” kérdésre alapvetően két modellezői megoldás ismert. Az egyik lehetőség a talajjellemző modellszámítás előtti átlagolását követő modellszámítás, míg a másik lehetőség a mérési, mintavételi pontokra történő modellszámítás eredményeinek interpolációval történő területi átlagolása és kiterjesztése (STEIN et al., 1991). Szerzők azt is kimutatták, hogy az interpolációs eljárás a megfelelőbb és pontosabb megoldás, összehasonlítva a hagyományos, kézi kontúrrajzolással. Az interpolációs technikák alkalmazásának további előnye, hogy azokban a területi (térbeli) változatosság leírása statisztikai függvénnyel történik, valamint a szerkesztett térkép információtartalmát is megadják. Környezetszennyezési példa található erre STARITSKY és munkatársai (1992) közleményében, amiben az alkalmazott interpolációs területi felosztással (krígelési eljárás) a szennyezési határérték túllépésének valószínüségét jelölik meg (YATES et al., 1986; FINKE, 1993). Természetesen a geostatisztika csak abban az esetben alkalmazható ilyen és ehhez hasonló feladatokra, ha a szemivariancia függvény térbeli struktúrát mutat. Ellenkező esetben a klasszikus statisztika átlaga és szórása az, amellyel a térbeli változatosságot leírhatjuk.

Talajfelvételezési adatok feldolgozása esetében ismerni kell a felvételezés idejét, az elemzési eredmények publikálásának idejét, a térképezés méretarányát, a felvételezés módszertanát, a becsült értékek pontosságát stb. A talajfelvételezési adatokat nem szabad érvényességi korlátaikon túl kiterjeszteni. Amennyiben nagyobb, vagyis több különböző terület talajfelvételezési adatainak feldolgozása a feladat, biztosítani kell a felvételezőkkel történő konzultáció lehetőségét annak érdekében, hogy az adatbázis folytonossága és pontossága felmérhető legyen. 


\section{A szabadföldi tapasztalatok kifejtése a modellekben}

A modellezés és a modellalkalmazás egyre inkább köznapivá, szélesebb körben alkalmazottá válik. Ennek következtében az átgondolás nélküli modellalkalmazásnak a reális veszélye megnőtt. Példaként a Darcy-törvényre alapozott víz- és anyagáramlási modell alkalmazása említhető makropórusos és rétegezett talajra, amelyre az nem megfelelö. Az is igaz, hogy a talaj fizikai, kémiai és biológiai folyamatai nem elkülönülten, hanem egyidejüleg, egymással kölcsönhatásban játszódnak le, olyan összetett módon, ahogy azt még a legbonyolultabb modellek sem képesek utánozni.

Szükséges emiatt a modellhasználat ellenőrzéséhez és eredményeinek érvényesítéséhez (kalibrálás és validálás) a szabadföldön adatokat gyüjteni. Az adatgyüjtést segítik a területet közvetlenül nem bolygató mintagyüjtési módszerek, mint a távérzékelési (a talajba hatoló radar, az elektromágneses indukció, az infravörös fényképezés stb.) és a helyszíni telepítésủ adatgyüjtö/monitorozó eljárások. Az adatgyüjtés mellett azonban szükség van a területet ismerő talajfelvételező tapasztalatainak figyelembe vételére és beépítésére is. Példa erre az adott területre készített talajtérkép foltelhatárolási szempontjainak tanulmányozása a geostatisztikai interpolációs eljárások alkalmazása előtt, vagy általánosságban a szakértői ismeret begyüjtése a modell használatát megelözően (STEIN et al., 1988). A szimulációs modellek alkalmazására vonatkozóan alapvető, koncepcionális szemléletủ meghatározás kidolgozása azonban még várat magára.

BouMA (1993) szerint szimulációs modell alkalmazása abban az esetben idokolt, amikor a rendelkezésre álló szakismeret a kérdés megválaszolására nem elégséges. A modellalkalmazás azonban nem ezen elvek szerint fejlődött. A 90-es évek elején a nem, vagy kevéssé kvantifikált szakismeretet a kvantifikált ismeretekkel összekapcsoltan alkalmazó vegyes modellek, vagyis a szakértői rendszerek (expert systems) kerültek kidolgozásra (VAN LANEN et al., 1992; VAN WANBEKE \& ROSSITER, 1992).

\section{A szakértői rendszerek alapvető ismérvei}

A 80-as években a mesterséges intelligencia (artificial intelligence) kialakítására irányuló kutatások intenzitása megnőtt. Különösen a tudás-alapú rendszereké (knowledge-based systems), amelyek a mesterséges intelligencia első hasznosítható termékeiként kerültek a figyelem középpontjába. A tudás-alapú rendszerek megnevezést általában olyan információs rendszerekre alkalmazták, amelyekben az emberi tudást a gondolkodásra emlékeztető szimbolikával állították össze. A tudás-alapú rendszerek közül a szakértői rendszerek lettek a legsikeresebbek. A szakértői rendszerek azok, amelyek bizonyos speciális területek aktuális kérdéseire/problémáira adnak választ/megoldást, vagy tanácsot olyan módon, ahogy azt az adott terület szakértői tennék. Magának a szakértői rendszernek az építése külön szakmának tekinthető, tudás-mérnökségként (knowledge engineering) ismert.

Azok a szakmai problémák, amelyekre szakértői rendszereket építenek a megoldásukhoz rendszerint jelentős szakértői tudást, és emberi erőfeszítést igényelnek.

Annak ellenére, hogy a szakértői rendszerek a szakértői tudást az emberi problémamegoldás logikája szerint építik fel, kezelésükhöz és használatukhoz számítógép és speciális programnyelv szükséges. 
A számítógépeket eredetileg számtani műveletek végzésére tervezték és már kezdetben volt egy szük felhasználói csoport, amelyik nem számítási felhasználásra kívánta azokat használni. Elhatározásuk már 1956-ban, a Dartmouth Nyári Szemináriumon a mesterséges intelligencia (MI), vagyis olyan számítógépi rendszer létrejöttét eredményezte, amelynek mintája az emberi viselkedéshez hasonlítható. Az első időkben a figyelem az elméleti tételbizonyításra és a problémamegoldásra irányult.

A hazai talajtanban a klímaváltozás következtében a Közép-Tiszavidék szikes talajain várható talajtani hatások összegyüjtése és szakértői rendszerbe foglalása történt meg (pl. FEHÉR et al., 1999).

\section{A paraméterek változatossága a modellszámításokban}

Két lehetőség közül az egyik a reprezentatív, vagyis a jellemző talajszelvény mért adataival, mint a talajfoltra általánosan/átlagosan jellemző paraméterértékekkel történő modellszámítás, a másik a mért pont adatokra történő modellfuttatás, amelyek interpolációjával nyerhető megfigyelés a területi eloszlásra. A pontadatokkal történő számításmenet hibája csupán a pontokra vonatkozó modellparaméterek mérési/becslési hibájából adódik. Például a talaj vízszolgáltató kapacitásának számításához mind a víztartó-, mind a vízvezetőképességi adatok szükségesek. Ezek az adatok kimérhetők, de a mérés költséges és időigényes. Lehetőség van egyéb könnyen mérhető talajjellemzők alapján a víztartási- és vízvezetési függvények más talajtulajdonságok mért értékeit felhasználó, pedotranszfer függvényekkel (BOUMA, 1989) történő becslésére is, pl. folyamatos regressziós függvényekkel (RAJKAI et al., 1981; COSBY et al., 1984), vagy egyegy talajcsoportra vonatkozó pedotranszfer függvényekkel (class pedotransfer functions) (WöSTEN et al., 1985; FINKE et al., 1991).

A csoport pedotranszfer függvények érvényessége aszerint meghatározott, hogy mi volt a csoportképzés alapja. Lehetséges csoport például a genetikai színt, a talajréteg, a talajképző kőzet, a talajtípus vagy altípus, termékenységi kategória, talajfolt stb. Bizonyos, hogy a becsült paraméter hibája általában ismeretlen.

WÖSTEN és munkatársai (1990) összehasonlították a különböző pedotranszfer függvényekkel becsült talajparaméterekkel szimulált talajvízmérlegeket. Azt tapasztalták, hogy a becslésből származó eredmények a direkt mérési eredményekből számítotthoz képest nem különböznek szignifikánsan. Az eredmény megegyező a korábban a menynyiségi és a minőségi talajjellemzők között tapasztalttal, vagyis a hidrológiai talajjellemzők változatossága jelentősen csökken, amikor azokból, pl. a szabadföldi vízkapacitás és a hervadáspont értékekből minőségi jellemzőt, a talaj vízszolgáltató kapacitását számítják.

A pontadatokkal végzett szimulációkat a mérés és az ahhoz társuló számítás ún. kísérleti hibája terheli. A kísérleti módszer megváltoztatása továbbá olyan hibát eredményezhet, amelyre vonatkozóan adat a módszer leírásában sem található (BOUMA, 1983). A talaj hidrofizikai függvényeinek az adott terület pontjaira jellemző változatossága sokkal inkább kifejezhető a víztartóképesség görbék sorozatával, mint egyetlen ún. területi átlaggörbével. A modellszámítások azután a görbesorozatból valamely véletlen módon (pl. Monte-Carlo módszerrel) kiválasztott görbékkel végezhetők. A módszert a különböző müvelésű talajok és gyepek peszticid-kimosódása (PETACH et al., 
1991), vízszolgáltató kapacitása, levegőzöttsége és gépjárhatósága változatosságának elemzésére alkalmazták (BOUMA \& BROEKE, 1993). Ha a szimuláció több évre készül nemcsak a térbeli, de az időbeli változatosságra is nyerhető információ.

Tekintettel arra, hogy az említett szimulációs modellezési munkák csupán néhány talajparaméter változtatására épültek, megjegyezzük itt, hogy előzetesen érzékenységi elemzéssel szükséges kiválasztani azokat a paramétereket, amelyekre a modell az adott szempontból a leginkább érzékeny. Az ajánlott módszer egyben a modellben szereplő folyamatokat dominanciájuk szerint is rangsorolja. A modell bonyolultsága ennek figyelembe vételével választható meg, és a feltétlenül szükséges adatigény is előzetesen meghatározható.

\section{A modell minősítése}

Annak megítélése, hogy a valóságos történéseket közelítően és egyszerüsített módon leíró számítógépes modellek szimulációs eredményei mennyire tekinthetők a modellezett rendszer valóságos válaszának - a modellezés lényeges kérdései közé tartozik. A „,szokásos” megoldás a számítógépes szimuláció gyakorlatában az, hogy a szimulációs eredményeket a modellezett rendszerben, a modellezett talajtulajdonságra mért valós értékekkel hasonlítják össze. Akkor tekinthető a szimuláció ideálisan megfelelőnek és a modellezés kellően pontosnak, amikor a szabadföldön vagy a laboratóriumban mért, valamint az ugyanarra a talajjellemzőre számított szimulációs eredmények egybeesnek.

Tekintettel azonban arra, hogy a mért értékek minimálisan mérési hibával, esetenként mintavételi és mérési hibával is terheltek, általánosabb érvényű a szimuláció megfelelőségének az a meghatározása, amely a szimulációt akkor ítéli jónak, ha a szimulált és a mért értékek eltéréseinek értéke kisebb, mint a mért értékek mérési hibája (WHITMORE, 1991).

ADDISCOTT és WHITMORE (1991) meghatározták a mért adatok és a modell eredmények közötti különbségek kifejezésének lehetséges módjait. Ezek egyike a mért és szimulált értékek páronként vett korrelációja (r), másika pedig azok átlagos eltérése $(\mathrm{M})$.

$$
\mathrm{M}=\frac{1}{\mathrm{~N}} \sum_{\mathrm{i}=1}^{\mathrm{N}}\left(\mathrm{y}_{\mathrm{i}}-\mathrm{x}_{\mathrm{i}}\right)
$$

ahol: $\mathrm{y}_{\mathrm{i}}$ az $i$-edik mért érték, $\mathrm{x}_{\mathrm{i}}$ pedig az $i$-edik szimulációs érték, $\mathrm{N}$ a mért és a szimulált értékpárok száma

RICHTER és munkatársai (1985) szerint amennyiben az $\left(\mathrm{y}_{\mathrm{i}}-\mathrm{x}_{\mathrm{i}}\right)$ különbségek legalább $90 \%$-a kisebb, mint egy szakmailag megállapított elfogadható érték - pl. a talajnedvesség-tartalomra a 2,5\% - teljesülése esetén a szimuláció megfelelőnek értékelhető. További lehetőséget jelent a szimuláció jóságának megállapítására az ún. reziduális hiba elemzése, amikor is az eltérés hibanégyzet-összegét a teljes mérési hibanégyzetösszeghez hasonlítják (pl. GREENWOOD et al., 1985).

Amennyiben kellő ismétlésszámú mért adat áll rendelkezésre a Student-féle t-próba (SNEDECOR \& COCHRAN, 1980) segítségével ellenőrizhető, hogy a szimuláció hibája a mérési hibánál kisebb-e. Formulával: 


$$
\mathrm{t}=(\overline{\mathrm{y}}-\mathrm{x}) / \mathrm{SE}=\overline{\mathrm{d}} / \mathrm{SE}
$$

ahol: $\bar{y}$ a mért értékek átlaga, $\overline{\mathrm{d}}$ a szimulált és a mért átlag értékek közötti eltérés (átlagos eltérés), SE a mérés standard hibája

A t-próbát pl. SHUTHERLAND és munkatársai (1986) alkalmazták szimulációs eredményeik jóságának megállapítására. Megjegyzendő, hogy a t-próba csupán kellő számú ismétléssel mért minta esetében alkalmazható, amikor is a minta szabadságfoka kellően nagy.

Statisztikai módszerek állnak rendelkezésre a mért és a szimulált értékek közötti eltérések véletlen (random) és nem véletlen (szisztematikus) voltának az elemzésére. A szisztematikus hiba az illesztetlenséget fejezi ki. A mért értékek és a szimulált értékek eltéréseinek négyzetösszegét bontják fel a véletlen hibát kifejező hiba négyzetösszegre, és az illesztetlenséget kifejező eltérés négyzetösszegre. A négyzetösszeg értékeket a szabadságfokkal leosztva nyerhető az átlagos négyzetes eltérés, és az illesztetlenségi variancia. A hiba- és az illesztetlenségi variancia viszonya F-statisztikával elemezhető. Amennyiben az illesztetlenségi hiba nagyobb, mint a véletlen hiba a modellen még javítani szükséges. Az eltérés négyzetösszeg minimuma alkalmas a modellparaméterek optimális értékeinek a kikeresésére, amely eljárás egyben a modell eredmények mérési adatokra történő illesztését is jelenti. Ebböl következik, hogy ez a statisztika jellemzi a modellbecslés jóságát, összehasonlítható általa különböző modellek becslési jósága, és kiválasztható segítségével a legalkalmasabb modell is. kezésre.

Összefoglalóan modell jóság tesztelésére alapvetően három lehetőség áll rendel-

1. Nincs, vagy csupán néhány párhuzamos mért adat áll rendelkezésre. Ekkor a legjobb modellparaméter értékek a legkisebb eltérés négyzetösszeghez rendelhetők. A modell jóság elemzésére használjuk ekkor a korrelációs együtthatót (r) és az átlagos különbséget (M). Határozzunk meg elfogadható hibaértéket és nézzük meg, hogy a szimulált értékek hány \%-a teljesíti azt. A modelleket minősítsük az elfogadható hibára adott válasz alapján.

2. Valamennyi, vagy a legtöbb mérés ismétléses. A mért és a szimulált értékek eltérés négyzetösszegét bontsuk véletlen és szisztematikus hibaösszetevőre. A legjobb modellparaméter értékeket a szisztematikus, vagy illesztetlenségi hiba minimalizálásával keressük. Az illesztetlenséget kifejező eltérés négyzetösszeg lehetőség szerint legyen nulla. Amennyiben a szisztematikus hiba nagyobb, mint a tiszta hiba, vizsgáljuk meg a kísérleti eredményeket. Amennyiben a szisztematikus hiba lényegesen nagyobb a véletlen hibánál a modell alkalmassága vizsgálandó (nem a megfelelő paramétereket veszi figyelembe, nem a megfelelő összefüggést használja stb.). Érdemes a modellt több kísérlet adatait tartalmazó adatbázison ellenőrizni. Ha a szisztematikus hiba csupán néhány kísérlet esetében nagyobb a véletlen hibánál, vagy az adatok ellenőrizendők, vagy a modellhasználat korlátozandó.

Modellek összehasonlítására az illesztetlenségi variancia illesztési hibaarány kevésbé alkalmas, mint az elfogadható hiba, hiszen szinte nincs olyan modell, amely 10 vagy 20 adatra ne adna statisztikailag szignifikáns eredményt. 
3. A vizsgált paraméter mind kezdeti, mind végső értékére ismétléssel mért értékek állnak rendelkezésre, pl. egy talajtulajdonság időbeli változásának szimulációja esetében.

A modell jóságának értékelése a 2. pont alatti módon történik. A paraméter-optimalizálás úgyszintén, viszont a szimulált eredmények eltérésének elemzésekor az eltérés elöjelét is figyelembe kell venni. A modellértékelés szintén a 2. pont elvei szerint történik.

Egy modell müködése azonban nem csupán a szimulációs pontosság alapján ítélhető meg. Érdekes az is, hogy a modell hogyan „reagál”, más kifejezéssel mennyire érzékeny paramétereinek az értékeire. A modellek ez irányú vizsgálata az érzékenységi elemzés.

\section{A modellek érzékenység vizsgálata}

A talaj-, illetve talajfolyamat-modellek „,ráhangolása” az éppen modellezendő talajra, általános értelemben esetre a modellparaméter értékei segítségével történik. A modellek bemeneti információit a paraméterek értékei, illetve az adatok alkotják. A paraméter az adott talajra, esetre vonatkozó mennyiségi állandó. Ebből következik, hogy a talajparaméter értéke esetről esetre változhat. Példaként vehető a talaj egy adott nedvességpotenciálon vett nedvességtartalma, amelynek értéke az adott talajra jellemző, de talajonként változó. Adat például a csapadékmennyiség, mert az nem köthető a talajhoz.

A talaj-, illetve talajfolyamat-modellek eltérő mértékben „érzékenyek” a különböző talajparaméterekre.

Következik mindebből, hogy célszerü a használni kívánt talajmodellt talajparaméterei értékére, illetve értékének változatosságára, azaz az átlagértékén kívül a varianciára mutatott érzékenységre is vizsgálni.

A modellek érzékenység elemzésének egyik szokásos módja a lehetséges paraméterérték-tartomány függvényében a modell eredményének az ábrázolása (ADDISCOTT, 1993). Az 5a. ábra a modellkimenet értékváltozását mutatja a paraméter értéktartományra. Azonban ez az ábrázolás csupán néhány paramétert tartalmazó modell esetében informatív. A többparaméteres modellek esetében az 5b. ábrán látható relatív modellkimeneti változás tájékoztat arról szemléletesen, hogy melyik paraméterre érzéketlen (C), melyik az, milyen mértékben, módon és irányban, amelyre pedig érzékeny (A és B) a modell.

Érdemes figyelni arra is, hogy a talajmodellek nemcsak paraméterekre érzékenyek, hanem bizonyos, a modellben szereplő tényezőkre is. A talajmodellek egyik érzékeny tényezője lehet a talajszelvény rétegfelosztása. A modell érzékenységét célszerü ezért a rétegfelosztásra (a talajrétegek számára és rétegvastagságára) is ellenőrizni (pl. ADDISCOTT \& WHITMORE, 1991).

A talajparaméterek szórása még egy mezőgazdasági táblán belül is különböző lehet, ezért ismernünk kell a paraméter változatosságának a modell eredményekre gyakorolt hatását. A modell érzékenység elemzésekor nem csupán azt szükséges vizsgálnunk, hogy a modell mennyire érzékeny a paraméter értékének bizonyos százalékú megváltozására, hanem azt is, mennyire érzékeny a paraméter varianciára (változatosságra). 


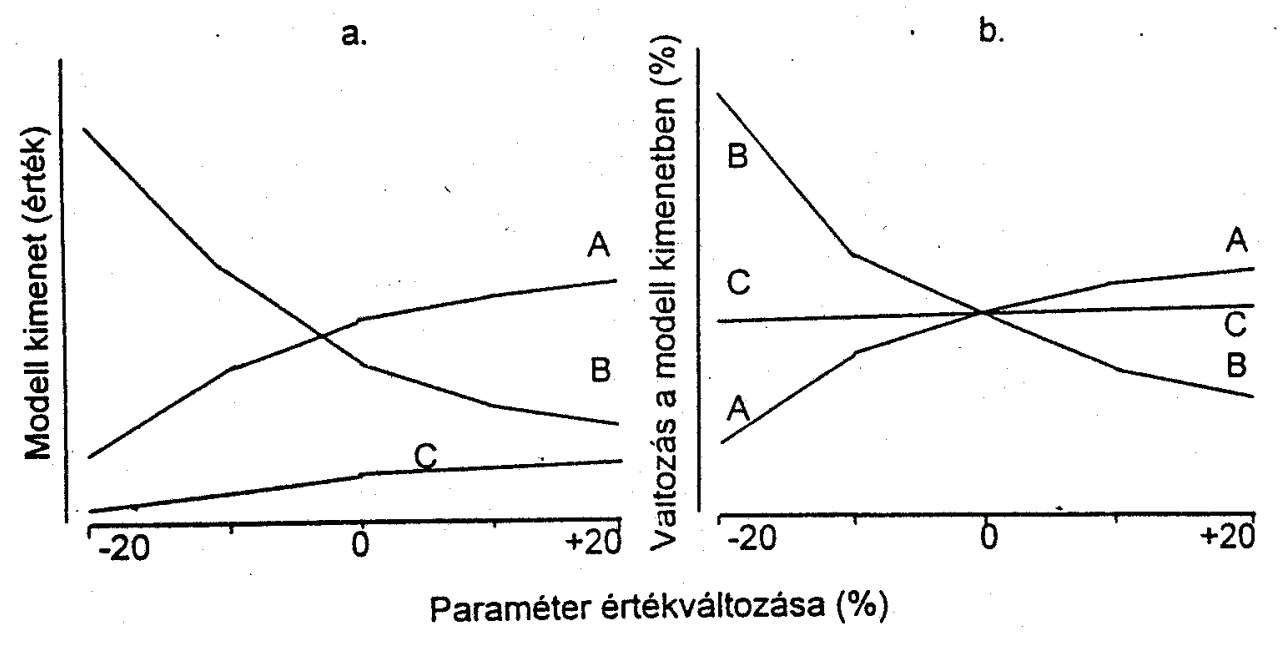

5. ábra

A modellérzékenység alakulása a paraméter értékváltozására abszolút értékben (a), ill. relatív értékben (b)

A statisztikai elvi alapot a paraméter változatosság vizsgálatához RAO és munkatársai (1977) közleményében találjuk meg, amelynek részletes ismertetésétől most eltekintünk. Egy talajmodell paramétere variációs együtthatójára mutatott érzékenységét a 6. ábrán mutatjuk be (ADDISCOTT, 1993). A 6a ábra a modellkimenet átlagának alakulását mutatja a paraméter variációs együtthatója a CV (a szórás és az átlag hányadosa \%-ban kifejezve) függvényében. Látható, hogy a $\mathrm{CV}$ növekedésével a modell eredmény változatlan maradhat (a modell érzéketlen, $\mathrm{C}=0$ ), az eredmény növekedhet ( $\mathrm{C}=$ pozitív), vagy csökkenhet $(\mathrm{C}=$ negatív). A modellérzékenység mértéke és elöjele a paramétert tartalmazó egyenlet, egyenletek második parciális differenciáljától függ.

A 6 b ábra azt mutatja, hogy a modell eredmény variációs együtthatója szintén a paraméter-változatosság függvénye, mégpedig az első parciális differenciál négyzete szerint. Ha az első parciális differenciál egységnyi, a paraméter CV és a modell eredmény CV hozzávetőleg azonos, vagyis a modell átviszi a paraméter CV-t. Amennyiben a parciális differenciál egynél nagyobb, a modell felerősíti, míg ha egynél kisebb, csökkenti a paraméter CV értékét az eredményben. Figyelemmel kell arra lenni, hogy a paraméter CV-re irányuló érzékenység vizsgálatban a paraméterek közötti korrelációk nyilvánvalóan fontosak.

A normáleloszlású paraméterek esetén a modell érzékenység vizsgálata során célszerü még a modellkimenet eloszlását is a paraméter $\mathrm{CV}$ függvényében megvizsgálni annak érdekében, hogy eldönthető legyen szükséges-e az eredményt a normalitás érdekében transzformálni.

A modellek paraméter érzékenységének vizsgálatára ADDISCOTT (1993) három megoldást mutat be: a Taylor módszert (RAO et al., 1977), a „szakaszoló módszert” 


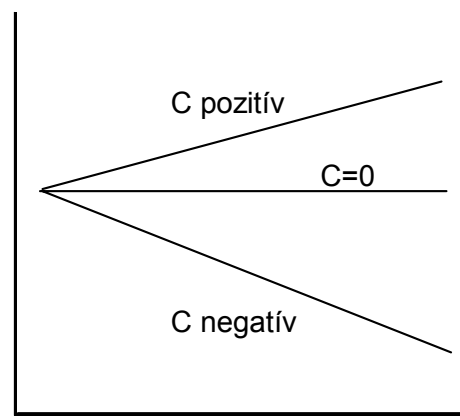

Paraméter CV

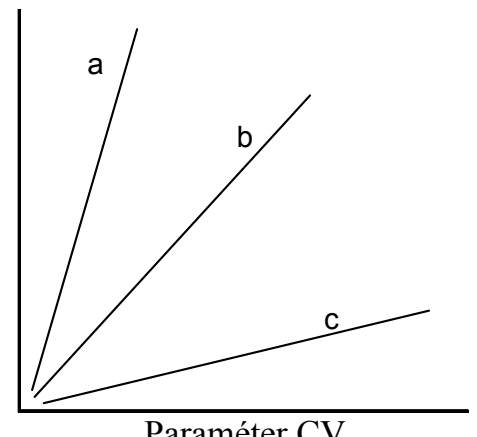

a) Felerősített vátozatosság

b) Átvett vátozatosság

c) Elnyomott vátozatosság

6. ábra

Talajmodellek érzékenysége a paraméterek változatosságára (ADDISCOTT (1993) nyomán)

(sectioning method) (ADDISCOTT \& WAGENET, 1985) és a Monte-Carlo szimulációs módszer bizonyos formáit.

A Taylor módszer a paraméter átlagának és varianciájának a vizsgálatára alkalmas, de nem vizsgálhatók segítségével a paraméterértékek eloszlási jellemzői, a ferdeség és terjedelem (skew és kurtosis).

A szakaszoló módszer a paraméterek értékeit azonos megfigyelés számú szakaszra osztja és a szakasz mediánt használja az eloszlás kifejezésére. A modellt valamennyi lehetséges paraméter és szakasz kombinációval futtatják és az eredmény alapján értékelik annak eloszlását.

A Monte-Carlo szimuláció minden egyes paraméter eloszlásából egy reprezentatív véletlen paraméter értéksort generál, amelyekből a modellkimenet eloszlások és eloszlásjellemzők nyerhetők.

A három bemutatott eljárás alkalmas a modellek minden egyes paramétere érzékenységének önmagában, illetve más paraméterek varianciájának egyidejü változtatásával történő vizsgálatára. Lényeges, hogy az érzékenység elemzést megelőzően minden egyes paraméter értékeloszlását normalizálni szükséges.

\section{Modellparaméterek és modellezési eredmények térbeli változatossága}

A talajtulajdonságok nemcsak paraméterértékekként mutatnak véletlen jellegű változatosságot, hanem lehetnek térben korreláltak (spatially correlated). Ekkor azonban statisztikai jellemzőiket a regionalizált változók elmélete alapján lehetséges megadni 
(MATHERON, 1965). A regionalizált változók elmélete szolgáltat alapot a súlyozott átlagú krigeléshez, amely révén a becslési hiba és variancia minimalizálható (JOURNEL \& HUIJBERGTS, 1978; WEBSTER \& OLIVER, 1990).

Amennyiben egy modellnek van olyan paramétere, amely kifejezett térbeli szerkezettel rendelkezik érdekes lehet számunkra a modell eredmény térbeli viselkedését ábrázoló függvénynek, a variogramnak a meghatározása és alkalmazása interpoláció céljára. Ezt a feladatot két úton végezhetjük el:

1. A modellt a paraméterek mért és interpolált értékeivel futtatjuk, majd a modell eredmény változójának határozzuk meg a variogramját és interpolálunk belöle.

2. Meghatározzuk minden egyes modellparaméter variogramját. A variogramok alapján interpolált értékeket készítünk általunk meghatározott koordinátájú pontokra. $\mathrm{Az}$ interpolált paraméterértékeket alkalmazzuk a modellben, és előre interpolált eredmény kimenetet állítunk elő.

A két eltérő módszer csak abban az esetben vezet azonos eredményre, ha a modell kimeneti változója, vagy eredményváltozója valamennyi modellparaméterrel lineáris viszonyt mutat. ADDISCOTT \& BAILEY (1990) szerint a SLIM kimosódási modell szignifikánsan eltérő eredményt szolgáltat aszerint, hogy az interpolációt a modellezés előtt vagy után végzik. A kapott eredmény nyilvánvalóvá teszi, hogy a SLIM modell eredménykimenete és a paraméterei között a kapcsolat nem lineáris.

DE JONG és munkatársai (1992) az időjárási adatok és a modell eredményének a térbeli átlagolását végezték el. Nem kaptak lényegesen eltérő eredményt, amikor az elvégzett térbeli átlagolás eredménye a hőmérséklettel volt kapcsolatos, és gyakorlatilag csak lényegtelen eltérésre vezetett, ha az eredmény a talajnedvességre vonatkozott. Az eredményt úgy értelmezték, hogy a vizsgált modell a hőmérsékletre és talajnedvességre nézve lineáris. A linearitás pedig feltétele a bemenő adatok, illetve az eredmények térbeli átlagolásának, vagy interpolációjának.

\section{A modellezés léptékváltása}

Nyilvánvaló, hogy egy modellt az érvényesítés léptékétől nagyobb léptékben használni nem problémamentes. Annak eldöntésére, hogy megengedett-e az eltérő léptékben való modellalkalmazás, a következők átgondolása tanácsolható:

1. Maradhat-e változatlan a modellben alkalmazott hipotézis?

2. Megmarad-e modellbe épített mechanizmus eredeti értelme?

3. Abban a paraméterérték-tartományban történik-e a modell használata, amelyre az érvényesítés vonatkozik?

4. Lehet-e valós, önálló értéket tulajdonítani a modell paramétereinek?

5. Illeszkedik-e a modellezés léptéke a paraméterértékek meghatározásának a léptékéhez?

6. A nagyobb lépték paraméterértékei jelentősen eltérnek-e a kisebb lépték paraméterértékeitöl? Ha igen, miért?

7. Változott-e a modell paraméter érzékenysége? Ha igen, miért?

8. Változott-e a modell típusa ténylegesen? Például, fizikairól (physically-based) összevont paraméterüre (lumped parameter), vagy mechanisztikusról müködésire? 
9. A nagyobb léptékben tapasztalható-e a modell müködésének olyan eleme, amely az elvárhatóval ellentétes?

A léptékváltás kapcsán feltétlenül figyelembe veendő, hogy a léptékkel nem csupán a fizikai méret változik, hanem a folyamatok kinetikája is. A kinetikai különbségekből adódik a történések időléptékének a változása. Nyilvánvaló, hogy a molekuláris lépték $(i-4)$ történésinek időtartama nem lehet azonos a talajszelvény szinten $(i)$ végbemenő folyamatokéval. A léptékváltás és annak kapcsán az 1-.9 kérdések áttekintése tér- és időlépték váltásból adódó eltérések áttekintését teszi szükségessé.

\section{A hazai talajtani modellfejlesztés és alkalmazás feladatai}

Talajfelvételi adatbázisok kialakítása. - A modellező talajtani szakemberek egyetértenek abban, hogy a modell eredmények hibaelemzése mind a modell kalibrációhoz, mind a modell érvényesítéséhez feltétlenül szükséges. Az is valószínü, hogy a szimuláció pontossága a bemenő adatok pontossága által meghatározott. Belátható, hogy az adatgyüjtést e kívánalomnak megfelelően szükséges kialakítani. Annak érdekében, hogy a tájelemek térbeli változatossága megfelelő módon kerüljön felvételre a térbeli/ területi sokféleséget nem átlagolással kell egy talajfoltra megadni, hanem keresztszelvény, vagy transzekt menti, illetve az elkülönülő, de ismert lokalizációjú talajmegfigyeléseket kell figyelembe venni. Minthogy a talajtani alaptulajdonságok begyüjtése és mérése idő- és költségigényes, azok nagy része becsléssel, illetve talajfelvételezési adatbázisok felhasználásával kerülhet megállapításra. Ebből következik, hogy a talajfelvételezési adatokból történő modellezés egyre inkább a folytonos és a csoportos pedotranszfer függvényekre (continuous- and class pedotransfer models) fog támaszkodni. A csoport pedotranszfer függvények talajfelvételezési szempontból informatívak, hiszen a talajgenetikai szintek jól definiáltak még tájléptékben is. Arra kell azonban a jövőben törekedni, hogy a talajfelvételezők által elkülönített talajszinteket, illetve rétegeket oly módon csoportosítsuk, hogy azok egyrészt jellemezzék a talaj függőleges és vízszintes anizotrópiáját, másrészt hordozzanak talajfolyamat és minőség jegyeket. A megoldást azon alaki (morfogenetikus) bélyegek kiválasztása fogja jelenteni, amelyek egyértelmüen valamely talajgenetikai folyamatot azonosítanak. Amenynyiben sikerül egy modellben összekapcsolni a talajgenetikai folyamatot és az annak eredményeként megjelenő morfogenetikai tulajdonságot, a szimulációs modell tartalmazza majd a genetikai folyamat hajtóerőit, a víz- és a tömegáramlást. Meggyőződésünk, hogy a vízmozgást leíró hidrológiai modellek adják majd azokat a szimulációs lehetőségeket, amelyek összekapcsolják a vízmozgást, az oldatmozgást, a kolloidszuszpenziók mozgását, a szervesanyag-képződést és az oxidációs, redukciós környezetet. Az áramlási modellek mellett diffúziós modellekre is szükség van a mállási és átalakulási folyamatok dinamikájának leírásában. A krigelési eljárások alkalmasnak látszanak arra, hogy a talajfejlődés szélsőséges eseményeit megjelenítsék, pl. egy kiemelkedő intenzitású vízáram előfordulásának valószínüségét, amely jelentős mennyiségü kolloidot és oldott anyagot szállít

A modell érzékenysége a bemenő adatra a modellben szereplő változótól függően más és más. Lehetséges, hogy a területen egy adott talajjellemző változatossága nagy, de a modell érzékenysége arra nézve kicsi, vagyis az a modell eredményét nem befolyásolja lényegesen. Előfordul, hogy a talajjellemző területi változatossága kicsi, de a 
modell eredményére gyakorolt nagy hatása miatt a modell eredményében megjelenik. Ebböl az következik, hogy területi modellezés kapcsán mind a területi variabilitást, mind a modell érzékenységet előzetesen mérlegelni szükséges annak érdekében, hogy meghatározhassuk, mely modellparamétereket elégséges hozzávetőlegesen becsülni és melyeket nagy pontossággal mérni.

Az is nyilvánvaló, hogy a táj léptékü modellezéshez nem feltétlenül szükségesek egyedien mért adatok. Kielégítő lehet pedotranszfer függvények, illetve kategória átlagértékek használata különösen akkor, ha azokra a modell nem érzékeny.

A hagyományos talajtanban a térbeli és időbeli változatosság inkább elméleti jelentőségü, mint a talajtan lényegét érintőnek minősülő. A modern talajtani információs rendszerekben azonban a térbeli változatosság más megvilágításba került, különösen azóta, hogy a szennyezésterjedés törvényi és közgazdasági szabályozása is lényegi környezeti kérdéssé lépett elö. Annak érdekében, hogy a környezeti modellek érzékenységét paramétereik térbeli szerkezetére vizsgálhassuk, a talajtulajdonságokra vonatkozó mintagyüjtést geosztatisztikai elemzésre is alkalmassá kell tenni. Ezt követően válik majd a modellek érzékenysége tesztelhetővé paramétereik térbeli szerkezetére, amely egyben megteremti a talajtérképezés objektív megvalósításának a lehetőségét is.

\section{Irodalom}

AdDiscott, T. M., 1993. Simulation modeling and soil behavior. Geoderma. 60. 15-40.

AdDiscotT, T. M. \& BAILEY, N. J., 1990. Relating the parameters of a leaching model to the percentages of clay and other components. In: Field-scale Solute and Water Transport Through Soil. (Eds.: RoTH, K. et al.) 209-221. Birkhauser. Basel.

Addiscott, T. M. \& WAGENET, R. J., 1985. Concepts of solute leaching in soils: A review of modelling approaches. J. Soil Sci. 36. 411-424.

Addiscott, T. M. \& Whitmore, A. P., 1991. Simulation of solute leaching in soils of differing permeabilities. Soil Use. Manag. 7. 94-102.

ANDERSON, J. L. \& Bouma, J., 1973. Relationship between conductivity and morphometric data of an argillic horizon. Soil Sci. Soc. Amer. Proc. 37. 408-413.

ARnold, R. W., Szabolcs, I. \& TARgulian, V. O., 1990. Global Soil Change. IIASA. Laxenburg. Austria.

Avery, B. W. \& Bullock, P., 1969. Morphology and classification of Broadbalk soils. Rep. Rothamsted Exp. Stn., 1968. Part 2. Rothamsted Exp. Stn. Harpenden. England..

Avery, B. W. \& King, D. W., 1971. Profile description of wilderness soils. Rep. Rothamsted Exp. Stn., 1970. Part 2. Rothamsted Exp. Stn. Harpenden. England.

Booch, G., 1991. Object-Oriented-Design with Applications. Benjamin/Cummings Publ. Co. Redwood City. CA.

Bootlink, H. W. G. \& Bouma, J., 1991. Physical and morphological characterization of bypass flow in a well-structured clay soil. Soil Sci. Soc. Am. J. 55. 1249-1254.

BoumA, J., 1983. Use of soil survey data to select measurement techniques for hydraulic conductivity. Agric. Water Manag. 6. 177-190.

Bouma, J., 1989. Using soil survey data for quantitative land evaluation. In: Advances in Soil Science. Vol. 9. (Ed.: STEWART, B. A.) 225-239. Springer Verlag. New York.

BoumA, J., 1993. Soil behavior under field conditions: Differences in perception and their effects on research. Geoderma. 60. 1-14.

BoumA, J. \& ANDERSON, J. L., 1973. Relationships between soil structure characteristics and hydraulic conductivity. In: Field Soil Moisture Regime. (Ed.: BRUCE, R. R.) 77-105. SSSA Spec. Publ. No. 5. SSSA. Madison, WI. 
BoumA, J. \& DenNing, J. L., 1972. Field measurement of unsaturated hydraulic conductivity by infiltration through gypsum crusts. Soil Sci. Soc. Amer. Proc. 36. 846-847.

Bouma, J. \& Hack-Ten Broeke, M. J. D., 1993. Simulation modeling as a method to study land qualities and crop productivity related to soil structure differences. Geoderma. 57. 51-67.

Bouma, J. \& van LANEN, H. A. J., 1987. Transfer funktions and threshold values: From soil characteristics to land qualities. In: Proc. ISSS/SSSA Workshop Quantified Land Evaluation Procedures, Washington, D. C., 27 April-2 May 1986. (Eds.: BEEK, K. J. et al.) 106-111. Int. Inst. Aerospace Surv. Earth Sci. Publ. No. 6. Enschede. The Netherlands.

Brimhall, G. H. et al., 1991. Deformational mass transport and invasive processes in soil evolution. Science (Washington, D. C.) 255. 695-702.

Chadwick, O. A., Brimhall, G. A. \& Hendricks, D. M., 1990. From a black box to a gray box - a mass balance interpretation of pedogenesis. Geomorphology. 3. 369-390.

CosBY, B. J. et al., 1984. A statistical exploration of the relationships of soil moisture characteristics to the physical properties of soil. Water Resour. Res. 20. 682-690.

Delcourt, H. R. \& Delcourt, P. A., 1988. Quaternary landscape ecology: Relevant scales in space and time. Landscape Ecol. 2. 23-44.

DE JONG, R., DuMANSKI, J. \& BoOTSMA, A., 1992. Implications of spatial averaging weather and soil moisture data for broad-scale modelling activities. Soil Use Manag. 8. 74-79.

DokucsajeV, V. V., 1883. Ruszkij csernozem., St. Petersburgh.

Evans, C. V. \& Roth, D. C., 1992. Conceptual and statistical modes to characterize soil materials, landform and processes. Soil Sci. Soc. Am. J. 52. 1104-1107.

FEHÉr J., RAJKAI K. \& MOLNÁR E., 1999. A SZALINEXP szakértői rendszer. Agrokémia és Talajtan. 48. 491-500.

FINKE, P. A., 1993. Field scale variability of soil structure and its impact on crop growth and nitrate leaching in the analysis of fertilizing scenarios. Geoderma. 60. 89-107.

FinKe, P. A. \& SteIn, A., 1994. Application of disjunctive co-kriging to compare fertilizer scenarios on a field scale. Geoderma. 62. 247-263.

Finke, P. A., BoumA, J. \& STEIN, A., 1992. Measuring field variability of disturbed soils for simulation purposes with geostatistical and morphological techniques. Soil Sci. Soc. Am. J. 56. $187-192$.

Greenwood, D. J., Neeteson, J. J. \& Drayscott, A., 1985. Response of potatoes to N fertilizer: dynamic model. Plant Soil. 85. 185-203.

GRUNWALD, S. et al., 2000. Soil landscape models at different scales portrayed in virtual reality modeling language. Soil Sci. 165. 598-615.

HAVENS, M. W., 1988. A GIS-based soil-landscape modeling approach to predict surface rock fragment distributions. M.Sc. thesis. Pennsylvania State Univ.

Hoffman, O., 1991. Conclusions of BIOMOVS phase I. Proc. Meet. Validity Environ. Transfer Models, Swedish Radiation Protection Inst., Stockholm, Sweden.

Hoosbeek, M. R. \& BRyAnt, R. B., 1992. Towards the quantitative modeling of pedogenesis-A review. Geoderma 55. 183-210.

Hutson, J. L. \& WAGENET, R. J., 1992. LEACHM, Leaching Estimation and Chemistry Model. Version 3.0 Dep. SCAS Res. Rep. 92-3. Cornell Univ. Ithaca. NY.

JACOBSON, I., 1993. Time for a cease-fire in the methods war. J. Object-Orient. Program. 6. $6-84$.

JenKinson, D. S., 1971. The accumulation of organic matter in soil left uncultivated. Rep. Rothamsted Exp. Stn., 1970. Part 2. Rothamsted Exp. Stn. Harpenden. England.

JenNy, H., 1941. Factors of Soil Formation - A System of Quantitative Pedology. McGraw-Hill. New York. 
JenNY, H., 1980. The Soil Resource: Origin and Behavior. Ecol. Stad. 37. Springer Verlag. New York.

Journel, A. G. \& Huijbregts, CH. J., 1978. Mining Geostatistics. Academic Press. London.

JuHÁsZ-NAGY P. , 1993. Az eltünő sokféleség. Scientia Kiadó. Budapest.

Katchalsky, A. \& Curran, P. F., 1967. Nonequilibrium thermodynamics in biophysics. Harvard Univ. Press. Cambridge, MA.

KIRKBY, M. J., 1985. A basis for soil profile modeling in a geomorphic context. J. Soil Sci. 36. 97-121.

LAUREN, J. G. et al., 1988. Variability of saturated hydraulic conductivity in a Glossaquic Hapludalf with macropores. Soil Sci. 145. 20-28.

LeE, K. S., LeE, G. B. \& TYler, E. J., 1988. Thematic mapper and digital elevation modeling of soil characteristics in hilly terrain. Soil Sci. Soc. Am. J. 52. 1104-1107.

Levine, E. R. \& Ciolkosz, E. J., 1986. A computer simulation model for soil genesis applications. Soil Sci. Soc. Am. J. 50. 661-667.

LuCAS, P. \& VAN Der GaAG, L., 1991. Principles of Expert Systems. Addison-Wesley Publ. Co. New York.

MANLey, E. P., Chesworth, W. \& Evans, L. J., 1987. The solution chemistry of podzolic soils from the eastern Canadian shield: A thermodynamic interpretation of the mineral phase controlling soluble $\mathrm{Al}^{3+}$ and $\mathrm{H}_{2} \mathrm{SiO}_{4}$. J. Soil Sci. 38. 39-51.

Marion, G. M., Schlesinger, W. H. \& Fonteyn, P. J., 1985. CALDEP: A regional model for soil $\mathrm{CaCO}_{3}$ (caliche) deposition in southwestern deserts. Soil Sci. 139. 468-481.

MAtheron, G., 1965. Les Variables Régionalisées et Leur Estimation. Masson. Paris.

MAYER, L., 1985. The distribution of carbonate in soils: A computer simulation using program CALSOIL. U.S. Geol. Surv. 975. U.S. Geol. Surv. Menlo Park, CA.

MeYer, B., 1988. Object-oriented Software Construction. Prentice-Hall. New York.

MokmA, D. L., 1987. Soil variability of five landforms in Michigan. Soil Surv. Land Eval. 7. 2531.

Morgan, R. P. C., 1986. Soil Erosion and Conservation. Longman Sci. Tech. Harlow. England.

NORDT, L. C., JACOB, J. S. \& WILDING, L. P., 1991. Quantifying map unit composition for quality control in soil survey. In: Spatial Variabilities of Soils and Landforms. (Eds.: MAUSBACH, M. J. \& Wilding, L. P.) SSSA Spec. Publ. 28. 183-197. SSSA, Madison, WI.

Peyton, R. L. et al., 1992. Applying X-ray CT to measure macropore diameters in undisturbed soil cores. Geoderma. 53. 329-341.

Petach, M. C., Wagenet, R. J. \& De Gloria, S. D., 1991. Regional water flow and pesticide leaching using simulations with spatially distributed data. Geoderma. 48. 245-269.

RAJKAI K. et al., 1981. A pF-görbék számítása a talaj mechanikai összetétele és térfogattömege alapján. Agrokémia és Talajtan. 30. 409-438.

RAO, P. S. C., RAO, P.V. \& DAvidSOn, J. M., 1977. Estimation of the spatial variability of the soil-water flux. Soil Sci. Soc. Amer. Proc. 41. 1208-1209.

RichaRdSON, J. L., Wilding, L. P. \& DANIEls, R. B., 1992. Recharge and discharge of groundwater in aquatic conditions illustrated with flow net analysis. Geoderma. 53. 65-78.

RiChTER, J., 1987. The Soil as a Reactor. Catena Verlag. Cremlingen. Germany.

Richter, J., Nordmeyer, H. \& Kersebaum, K. C., 1985. Simulation of nitrogen regime in loess soils in the winter half-year: Comparison between field measurements and simulations. Plant and Soil. 83. 419-431.

Rumbaugh, J. et al., 1991. Object-oriented Modeling and Design. Prentice-Hall, Inc. New Jersey.

RUNGE, E. C. A., 1973. Soil development sequences and energy models. Soil Sci. 115. 183-193.

Shovic, H. F. \& Montagne, C., 1985. Application of a statistical soil-landscape model to an order III windland soil survey. Soil Sci. Soc. Am. J. 49. 961-968. 
Smeck, N. E., Runge, E. C. A. \& Mackintosh, E. E., 1983. Dynamics and genetic modelling of soil systems. In: Pedogenesis and Soil Taxonomy 1. Concepts and Interactions. (Eds: WILDING, L. P. et al.) 23-49. Elsevier. Amtserdam.

Snedecor, G. W. \& Cochran, W. G., 1967. Statistical Methods. Iowa Sta. Univ. Press. Iowa.

Soil Survey Staff, 1983. National Soils Handbook. U.S. Gov. Print. Office. Washington, D. C.

Sposito, G. \& Reginato, R., 1992. Opportunities in Basic Soil Science Research. SSSA. Madison, WI.

Staritsky, I. G., Sloot, P. H. M. \& Stein, A., 1992. Spatial variability and sampling of cyanide polluted soil on former galvanic factory premises. Water Air Soil Pollut. 61. 1-16.

SteButT, A., 1930. Lehrbuch der allgemeinen Bodenkunde. Borntraeger. Berlin.

STEFANOVits P., 1963. Magyarország talajai. 2. kiadás. Akadémiai Kiadó. Budapest.

Stefanovits P. 1975. Talajtan. Mezőgazdasági. Kiadó, Budapest.

Stefanovits P. Filep Gy \& FÜleky Gy., 1999. Talajtan. Mezőgazda Kiadó. Budapest.

STEIN, A. et al., 1991. Simulation of moisture deficits and areal interpolation by universal cokriging. Water Resour. Res. 27. 1963-1973.

Stein, A., Hoogerwerf, M. \& Bouma, J., 1988. Use of soil map delineations to improve (co)kriging of point data on moisture deficits. Geoderma. 43. 163-177.

Stumm, W. et al., 1985. The effects of complex-forming ligands on the dissolutiom of oxides and aluminosilicates. In: The Chemistry of Weathering. (Proc. NATO Advanced Res. Workshop on the Chemistry of Weathering, Rodez, France) NATO ASF Ser. C. Vol. 149. (Ed.: Drever, J. I.) $55-74$.

Sutherland, R. A. et al., 1986. The deficiency of the "economic optimum" application for evaluating models which predict crop yield response to nitrogen fertilizer. Fertilizer Res. 10. 251-262.

UpChURCH, D. R., Wilding, L. P. \& HARTField, J. L., 1988. Methods to evaluate spatial variability. In: Reclamation of Disturbed Lands. (Ed.: HosSNER, L. R.) 201-229. CRC Press. Boca Raton, FL.

VAN LANEN, H. A. J. et al., 1992. A mixed qualitative/quantitative physical land evaluation methodology. Geoderma. 55. 37-54.

van Wambeke, A. R. \& Rossiter, D. G., 1992. Automated Land Evaluation System (ALES). Vers. 3. SCAS Teach. Ser. No. 2. Dep. Soil, Crop \& Atmospheric Sci. Cornell Univ. Ithaca, New York.

Vepraskas, M. L. \& BoumA, J., 1976. Model studies on mottle formation simulating field conditions. Geoderma. 15. 217-230.

Wagenet, R. J., Bouma, J. \& Grossman, P. B., 1991. Minimum data sets for use of soil survey information in soil interpretive models. In: Spatial variability of soils and landforms. (Eds.: Mausbach, M. J. \& Wilding, L. P.) 161-182. SSSA Spec. Publ. 28. SSSA, Madison, WI.

Webster, R. \& Oliver, M. A., 1990. Statistical Methods for Soil and Land Resource Survey. Calendron Press. Oxford.

Wegner, P., 1990. Concepts and Paradigms of Object-oriented Software Construction. PrenticeHall. New York.

WhitMORE, A. P., 1991. A method for assessing the goodness of computer simulation of soil processes. J. Soil Sci. 42. 289-299.

WiLding, L. P. \& DreEs, L. R., 1983. Spatial variability and pedology. In: Pedogenesis and Soil Taxonomy: I. Concepts and Interactions. (Eds.: WiLDING, L. P. et al.) 83-116. Elsevier Publ. Co. Amsterdam.

WiLding, L. P. \& HALlMARK, C. T., 1984. Development of structural and microfabric properties in shrinking and swelling clays. In: Proc. ISSS Symp. Water Solute Movement in Heavy Clay Soils, Wageningen, The Netherlands. (Eds.: BoumA, J. \& RAATs, P. A. C.) 1-22. ILRI Publ. 37. Wageningen, The Netherlands. 
Wösten , J. H. M., Bouma, J. \& Stoffelsen, G. H., 1985. The use of soil survey data for regional soil water simulation models. Soil Sci. Soc. Am. J. 49. 1238-1245.

Wösten, J. H. M. et al., 1990. Comparing four methods to generate soil hydraulic functions in terms of their effect on simulated soil water budgets. Soil Sci. Soc. Am. J. 54. 827-832.

YAtes, S. R., WARrick, A. W. \& Myers, D. E., 1986. Disjunctive kriging. 1 Overview of estimation and conditional probability. Water Resour. Res. 22. 615-621.

Érkezett: 2001. február 26.

RAJKAI KÁLMÁN

MTA Talajtani és Agrokémiai Kutatóintézet, Budapest 